\title{
Causes and hazards of the euro area sovereign debt crisis: Pure and fundamentals-based contagion
}

\author{
Marta Gómez-Puig ${ }^{a}$, Simón Sosvilla-Rivero ${ }^{\mathrm{b} *}$ \\ ${ }^{a}$ Department of Economic Theory, Universitat de Barcelona. 08034 Barcelona, Spain \\ ${ }^{b}$ Complutense Institute for International Studies, Universidad Complutense de Madrid. \\ 28223 Madrid, Spain \\ Revised version \\ February 2016
}

\begin{abstract}
This paper tries to contribute to the understanding of sovereign debt crises' pattern by empirically investigating the determinants of the recent euro area crisis to assess if its transmission was due to "pure" or "fundamentals-based" contagion. Using sovereign bond yield spreads with respect to Germany for a sample of ten central and peripheral countries from January 1999 to December 2012, we firstly examine the dynamic evolution of Granger-causality within the 90 pairs of yield spreads in our sample to detect episodes of contagion (associated with episodes of significant intensification in causality). Secondly, we make use of a logit model to explore whether there is evidence of "pure contagion" or "fundamentals-based contagion", by trying to determine which factors might have been behind the detected contagion episodes. Our results suggest that contagion episodes are concentrated just after the inception of the EMU and matching the global financial crisis, yielding more accurate and sensible indicators than those obtained from DCC-GARCH models used in prior studies. Indeed, they preceded the outburst of the global financial crisis (causality intensification is detected from March 2008), and reached a peak during January-May 2011. Furthermore, they underline the coexistence of "pure" and "fundamentals-based contagion" during the recent European debt crisis.
\end{abstract}

Keywords: Sovereign bond spreads, contagion, Granger-causality, time-varying approach, euro area, logit model.

JEL Classification Codes: C35, C53, E44, F36, G15

${ }^{*}$ Corresponding author. Tel.: +34 913942342; fax: +34 913942591

E-mail addresses: marta.gomezpuig@ub.edu (M. Gómez-Puig), sosvilla@,ccee.ucm.es (S. SosvillaRivero) 


\section{Introduction}

The announcement of Greece's distressed debt position in late 2009 triggered a sudden loss of investor confidence and marked the beginning of the euro area sovereign debt crisis. Indeed, in May 2010 Greece's financial problems became so severe that the country needed to be bailed out. An important reason for providing financial support to Greece was fear of contagion (see, e.g., Constâncio, 2012). This fear could be mainly explained by two facts: (1) several European Union (EU) banks had a high exposure to Greece (see Gómez-Puig and Sosvilla-Rivero, 2013); and (2) investors then turned their attention to the macroeconomic and fiscal imbalances within European Economic and Monetary Union (EMU) countries. So, from late 2009 onwards, in parallel with the higher demand for the German bund which benefited from its safe haven status, yield spreads of euro area issues with respect to Germany spiralled (see Figure 1). Besides, since May 2010, not only has Greece been rescued three times, but also Ireland, Portugal and Cyprus needed bailouts to stay afloat.

These events raised some important questions for economists, policymakers, and practitioners. To what extent was the sovereign risk premium increase in the euro area during the European sovereign debt crisis due only to deteriorated debt sustainability in member countries? Did contagion play any significant role in the increase in the sovereign risk premium? In fact, the sovereign debt crisis in Europe has rekindled the literature on contagion applied to the euro area [see Kalbaska and Gatkowski (2012), Metiu (2012), Caporin et al. (2013), Beirne and Fratzscher (2013), Mink and Haan (2013), or Ludwig (2014) to name a few], even though the empirical evidence is not conclusive. The inconsistencies between studies using different empirical approaches and applying different definitions of the crisis transmission channel have made it difficult to compare results and therefore to reach meaningful conclusions (Dungey et al., 2005). The main objective of this 
paper is to shed some light on this challenging avenue of research and to contribute to our understanding of the pattern we observe in sovereign debt crises.

In this context, since the term contagion has not been used with accuracy in the literature (as it will be explained in Section 2.1, two main groups of theories have been used to explain contagion), nor is there any agreement on the econometric methodology to be used to quantify it, our first contribution is to provide an operational definition of the term "contagion": an abnormal increase in the intensity of causal relationships. This definition will allow us to explore whether there is evidence of "fundamentals-based contagion" (if the abnormal increase can be explained by macroeconomic fundamentals, financial linkages or common regional/global shocks) or "pure contagion" (if it is only triggered by a shift in idiosyncratic market sentiments). The second contribution is an empirical one: contagion is an unobservable shock, and therefore most empirical techniques have problems dealing with latent variables. In this paper in order to tackle this issue, we first test for the existence of possible Granger-causal relationships between 10-year sovereign yield spreads over Germany of 10 EMU countries, both central (Austria, Belgium, Finland, France and The Netherlands) and peripheral (Greece, Ireland, Italy, Portugal and Spain) and, then, we examine the time-varying nature of these relationships in order to detect episodes of significant intensification in the causality between them ${ }^{1}$. Finally, the last and main contribution of the paper is the investigation of whether transmission of the recent crisis in euro area sovereign debt markets was due to pure or fundamentals-based contagion. To that end, we try to determine which factors (changes in local risk sentiment in each different country, fundamental variables, financial linkages, or common regional/global risk factors) might have been behind these intensification episodes.

\footnotetext{
${ }^{1}$ As it is shown in Section 3.5, our methodology yields to more accurate and sensible indicators than those obtained from DCC-GARCH models used in prior studies.
} 
The rest of the paper is organised as follows. Section 2 reviews the literature on financial contagion and on the determinants of euro-area sovereign bond spreads. The Grangercausality analysis and our approach for the detection of episodes of causality intensification (which we associate with contagion) are presented in Section 3. In Section 4 we carry out the empirical exploration of the determinants of these episodes. Finally, Section 5 summarises the findings and offers some concluding remarks.

\section{Literature review}

\section{1. Financial contagion}

Considerable ambiguity surrounds the precise definition of contagion. There is no theoretical or empirical definition on which all researchers agree; therefore, the debate on exactly how to define contagion is not just academic, but has important implications for measuring the concept and for evaluating policy responses. Pericoli and Sbracia (2003) note five definitions of contagion used in the literature, whilst The World Bank defines three layers within contagion ${ }^{2}$. First, in a broad sense, contagion is the cross-country transmission of shocks; in this sense, contagion can take place both during "good" and "bad" times and does not need to be related to crises. Second, in a restrictive sense, contagion is the transmission of shocks to other countries, or the cross-country correlation, beyond any fundamental link $\mathrm{k}^{3}$ between the countries and beyond common shocks. When either fundamentals or common shocks do not fully explain the relationship between countries, spillover effects are attributed to herding behaviour, either rational or irrational. Finally, in a very restrictive sense, according to the World Bank, contagion refers to increases in crosscountry correlations during "crisis times" relative to correlations during "tranquil times".

\footnotetext{
2 http:/ / go.worldbank.org/JIBDRK3YC0

3 The World Bank distinguishes three different categories of fundamental links: financial, real, and political. The first ones exist when two economies are connected through the international financial system. Real links are fundamental economic relationships between countries. These links have usually been associated with international trade, but other types of real links, like foreign direct investment across countries, may also be present. Finally, political links are the political relationships between countries. Although this link is much less stressed in the literature, when a group of countries share an exchange rate arrangement - a common currency in the case of the euro area countries - crises tend to be clustered.
} 
The second and third definitions of contagion proposed by the World Bank (contagion in a restrictive, and in a very restrictive sense) have predominantly been used in empirical studies analysing the concept in financial markets and have been adopted in common usage by governments, citizens and policymakers. The third defines contagion depending on whether the transmission mechanisms are stable through time, whilst the second defines it depending on the channels of transmission that are used to spread the effects of the crisis.

According to the very restrictive definition, which was proposed in a seminal paper by Forbes and Rigobon (2002), contagion is a significant increase in cross-market linkages after a shock to one country (or group of countries). Therefore, if two markets show a high degree of co-movement during periods of stability, even if they continue to be highly correlated after a shock to one market this may not constitute contagion. This definition implies the presence of a tranquil, pre-crisis period ${ }^{4}$.

By contrast, Masson (1999) and Kaminsky and Reinhart (2000) explore the restrictive definition of contagion, arguing that contagion arises when common shocks and all channels of potential interconnection are either not present or have been controlled for. According to these authors, "pure or true contagion" should be distinguished from "fundamentals-based contagion" which is caused by "monsoonal effects" and "linkages". Conversely, the term "pure contagion" is only applied when the transmission process itself changes when entering crisis periods: when a crisis in one country may conceivably trigger a crisis elsewhere for reasons unexplained by macroeconomic fundamentals - perhaps because it leads to shifts in market sentiment, or changes the interpretation given to existing information, or triggers herding behaviour. Different mechanisms have been proposed to explain herding behaviour by international investors and other cases of

\footnotetext{
4 The distinction between contagion which occurs at times of crisis, and the interdependence which is the result of normal market interaction, has become the focal point of many contagion studies (see, e.g., Corsetti et al., 2005).

5 "Monsoonal effects" are random aggregate shocks that hit a number of countries in a similar way (such as a major economic shift in industrial countries, a significant change in oil prices or changes in US interest rates) that may adversely affect the economic fundamentals of several economies simultaneously and, therefore, may cause a crisis. "Linkages" are normal interdependencies, such as those produced by trade and financial relations between countries and which can easily become a carrier of crisis.
} 
extreme market sentiment (see Akerlof and Shiller, 2009), but asymmetric information is at the root of those reactions.

All in all, then, the literature includes two groups of theories (not necessarily mutually exclusive - see Dungey and Gajurel, 2013) to explain crisis transmission mechanisms. One group argues that the economic fundamentals of different countries are interconnected by their cross-border flows of goods, services, and capital. When a crisis originates in one country, this interdependence of economies through real and financial linkages may become a conveyor of crisis. In addition, global phenomena or common shocks may adversely affect the economic fundamentals of several economies simultaneously, and may therefore cause a crisis. These fundamentals-based effects are also known as 'spillovers' (Masson, 1999), 'interdependence' (Forbes and Rigobon, 2002), or 'fundamentals-based contagion' (Kaminsky and Reinhart, 2000).

The other group of theories argues that financial crises spread from one country to another due to reasons not related to or explained by economic fundamentals, such as market imperfections of herding behaviour of international investors (Masson, 1999 or Mondria and Quintana-Domeque, 2013) ${ }^{6}$.

The initial empirical literature on financial crisis and contagion was focused on fundamentals-based mechanisms and directed towards developing an early warning system (Eichengreen et al., 1996; Kaminsky and Reinahrt, 2000) while later empirical works have focused on investor behaviour-based mechanisms (Dungey et al., 2005; Bekaert et al., 2014). The aim of this paper is to explore the extent to which the transmission of euro area debt crisis could be attributed to common shocks and/or interconnected markets (through real and financial linkages), to idiosyncratic factors (shifts in market participants behaviour

\footnotetext{
${ }^{6}$ A different story occurs when a crisis in one country could lead to a reassessment of objectively unchanged fundamentals in other countries. This is what Goldstein (1998) calls 'wake-up call' contagion since it leads market participants aware of existing problems or risks they failed to see before. Whilst some authors consider this sort of contagion a mechanism of 'pure contagion' propagation (Moser, 2003), others (Beirne and Fraszter (2013) or Ludwig (2014)) identify it as 'fundamentals-based' contagion since it is the result of an efficient correction and leads towards a more accurate assessment of fundamentals.
} 
during the crisis period), or to both types of factor. To this end, we will analyse which variables could be behind the crisis transmission in order to assess whether there is empirical evidence of "fundamentals-based contagion", or "pure contagion", or of a mixture of the two during the euro area sovereign debt crisis.

In addition, among the five general strategies ${ }^{7}$ that have been used in the empirical literature, our analysis will be related to one of the most conventional methodologies for testing for contagion: the analysis of cross-market correlations. However, we not only investigate changes in cross-market interdependencies via cointegration analysis, but also explore changes in the existence and direction of pair-wise causal relationships among euro area sovereign bond yield spreads vis-à-vis the German bund ${ }^{8}$. Hence, the two operational definitions of contagion that we will explore in the remainder of this paper are the following. We will identify "fundamentals-based contagion" as an abnormal increase in the intensity of causal relationships explained by macroeconomic fundamentals, financial linkages or common regional/global shocks, and "pure contagion" as an abnormal increase in the intensity of causal relationships only triggered by a shift in idiosyncratic market sentiments.

\subsection{Determinants of the evolution of euro-area sovereign yield spreads.}

In order to analyse the factors behind episodes of intensification of causality within sovereign yield spreads, we focus on the literature on the determinants of the evolution of euro-area sovereign yield spreads. This literature, combined with that of financial contagion, suggests that we should not only include variables that measure macroeconomic fundamentals or some potential channels of crisis transmission, but also those that capture

\footnotetext{
${ }^{7}$ Probability analysis, cross-market correlations, VAR models, latent factor/GARCH models, and extreme value/co-exceedance/jump approach (see Forbes, 2013).

${ }^{8}$ Forbes and Rigobon (2002) suggest the use of this methodology and note that, if the source of the crisis is not well identified and endogeneity may be severe, it may be useful to utilise Granger-causality tests to determine the extent of any feedback from each country in the sample to the initial crisis country.
} 
changes in market sentiment: either idiosyncratic, regional, or global'. A summary with the definition and sources of all the explanatory variables used in our analysis is presented in Appendix A.

Specifically, although pure contagion is the most difficult type of contagion to measure empirically as it partly reflects factors that are unobservable, we honestly think that it can be proxied using variables that capture market sentiment in each different country (see Appendix A1 to A3). To that end, following the literature, four variables have been used to gauge regional, global or local market sentiment in each country in our sample: stock returns, stock volatility, an index of economic policy uncertainty, and an index of the fiscal stance. Finally, the analysis of the influence of local, regional and global market sentiment on sovereign yield spreads' linkages has been completed by the inclusion of one more variable in the first case (the credit rating), five additional variables in the second (two variables that capture credit quality in the corporate market, a variable that captures interest rate volatility and two variables that gauge EMU instability and default risk), and two supplementary variables in the third (and index of the global risk aversion and the Kansas city financial stress index).

On the other hand, in order to measure the impact of fundamental variables (at both the local and the regional level) on sovereign spreads causal relationships, we use instruments that gauge not only each country's fiscal position, but the market liquidity in each country, its foreign debt, its potential rate of growth, and the loss of competitiveness as well (see Appendix A4 and A5). Besides, the private sector level of indebtedness has been added in the analysis of the effect of local fundamental variables.

Finally, according to certain authors (see Allen et al., 2011, among them), in a scenario of increased international financial activity in the euro area, not only are public finance imbalances key determinants of the probability that the sovereign crisis could spill over

\footnotetext{
${ }^{9}$ We expect the same sign for the effect of each of these variables on spreads and on the occurrence of a contagion episode.
} 
from one country to another, but its transmission through the banking system can also be a major issue. Consistently, in our analysis we also include variables that capture the important cross-border banking system linkages in euro area countries (see Appendix A6) ${ }^{10}$. All the variables included in the estimation that capture both macroeconomic fundamentals or financial linkages are in relative terms to the German ones, as our dependent variable is the difference between the 10-year sovereign yield of each country over Germany.

\section{Granger-causality analysis}

\section{1. Data}

The dependent variables in our empirical analysis are bond yield spreads, derived as differences between 10-year sovereign bond yields of EMU-founding countries and Greece and yields of the equivalent German bund. Therefore, our sample contains both central (Austria, Belgium, Finland, France and the Netherlands) and peripheral countries (Greece, Ireland, Italy, Portugal and Spain) ${ }^{11}$.

We use daily data from 1 January 1999 to 31 December 2012 collected from Thomson Reuters Datastream. The sample size is constrained by the availability of several explanatory variables used in the estimation of the logit model presented in Section $4^{12}$.

Table 1 presents descriptive statistics for the levels and differences of the bond yield spreads during the sample period. As can be seen, the mean is not significantly different from zero for the first differences. Normality is tested with the Jarque-Bera test (which is distributed as $\chi^{2(2)}$ under the null) and strongly rejected for both the levels and first differences. Since rejection could be due to either excess of kurtosis or skewness, we report these statistics separately in Table 1. Given that the kurtosis of the normal distribution is 3 ,

\footnotetext{
10 The construction and evolution of sectoral private debt and foreign banks claims (by sector and by nationality of reporting banks) are explained in Gómez-Puig and Sosvilla-Rivero (2013).

${ }^{11}$ Luxembourg is exempted from the present analysis, because of its very low level of outstanding sovereign bonds.

${ }^{12}$ Concretely, some of the instrumental variables used in the analysis have been constructed by other authors for a given period of time and kindly provided by them. Is the case of the index of the fiscal stance (Polito and Wickens, 2012); the interest rate volatility index (López and Navarro, 2013); the euro instability index (Klose and Weigert, 2012); and the euro area default risk (Lucas et al., 2013). This is the reason why the analysis ends in December 2012, since the above mentioned variables are not available beyond that date
} 
our results suggest that the distribution of the levels of sovereign yield spreads, as well as all the first differences, are peaked relative to the normal. Finally, regarding the asymmetry of the distribution of the series around their mean, we find positive skewness for all the variables in levels and for the first difference in the case of Austria, Belgium, Finland, the Netherlands and Portugal, suggesting that their distributions have long right tails, whilst in the cases of the first differences of bond yield spreads for Greece, Ireland, Italy and Spain there is evidence of negative skewness and therefore of distributions with long left tails.

[Insert Table 1 here]

Figure 1 plots the evolution of daily 10-year sovereign bond spreads for each country in our sample. A simple look at this figure indicates the differences in the yield behaviour before and after the outbreak of the Greek sovereign debt crisis at the end of 2009.

\section{[Insert Figure 1 here]}

Specifically, it is striking that between the introduction of the euro in January 1999 and November 2009, when it became clear that the Greek economy faced the bleak reality of being unable to finance its sovereign debt, spreads on bonds of EMU countries moved in a narrow range with only slight differentiation across countries. In fact, the stability and convergence of spreads was considered a hallmark of successful financial integration inside the euro area (neither the subprime crisis nor the Lehman Brothers collapse bit significantly into euro sovereign spreads).

Nevertheless, once the Global Financial Crisis began to affect the real sector, the imbalances within euro area countries were plain to see. Spreads, which had reached levels close to zero between the launch of the euro and October 2009 (the average value of the 10-year yield spread against the German bund moved between 10 and 47 basis points in the case of France and Greece respectively), have risen ever since. Indeed, the risk premium on EMU government bonds increased strongly from November 2009, reflecting investor 
perceptions of upcoming risks. Figure 1 shows that by late 2011 and beginning 2012 it reached maximum levels of 4680 basis points in Greece, 1141 in Portugal, 1125 in Ireland, 635 in Spain and 550 in Italy. This widespread increase in sovereign spreads meant that certain euro area Member States were under enormous pressure to finance their debt, and funding costs rose significantly. This led to an increase in rollover risk as debt had to be refinanced at unusually high costs and, in extreme cases, could not be rolled over at all, which triggered the need for a rescue (see Caceres et al., 2010).

Table 2 reports the correlation matrix for the levels of the bond yield spreads to have a first description of the degree of relationship between the variables under study. As can be seen, our results suggest a fairly strong positive relationship between our sample of bond yield spreads, ranging the cross-correlation from 0.5392 (between Finland and Greece) to 0.9730 (between Italy and Spain).

[Insert Table 2 here]

\section{2. Econometric strategy}

The concept of Granger-causality was introduced by Granger (1969) and Sims (1972) and is widely used to ascertain the importance of the interaction between two series. The central notion is one of predictability (Hoover, 2001): a variable $Y$ is said to Granger-cause another variable $X$ if past values of $Y$ help predict the current level of $X$ better than past values of $X$ alone, indicating that past values of $Y$ have some informational content that is not present in past values of $X$. Therefore, knowledge of the evolution of the variable $Y$ reduces the forecast errors of the variable $X$, suggesting that $X$ does not evolve independently of $Y$. 
Tests of Granger causality typically use the same lags for all variables. This poses a potential problem, since Granger-causality tests are sensitive to lag length ${ }^{13}$. In determining the optimal lag structure for each variable, we follow Hsiao’s (1981) sequential method to test for causality, which combines Akaike's final predictive error (FPE, from now on) and the definition of Granger-causality ${ }^{14}$. Essentially, the FPE criterion trades off the bias that arises from under-parameterisation of a model against a loss in efficiency resulting from its over-parameterisation, removing the ambiguities of the conventional procedure.

Consider the following models,

$$
\begin{gathered}
X_{\mathrm{t}}=\alpha_{0}+\sum_{i=1}^{m} \delta_{i} X_{t-i}+\varepsilon_{t} \\
X_{t}=\alpha_{0}+\sum_{i=1}^{m} \delta_{i} X_{t-i}+\sum_{j=1}^{n} \gamma_{j} Y_{t-j}+\varepsilon_{t}
\end{gathered}
$$

where $X_{t}$ and $Y_{t}$ are stationary variables [i.e., they are $\mathrm{I}(0)$ variables]. The following steps are used to apply Hsiao's procedure for testing Granger-causality:

i) Treat $X_{t}$ as a one-dimensional autoregressive process (1), and compute its FPE with the order of lags $m$ varying from 1 to $m^{15}$. Choose the order which yields the smallest FPE, say $m$, and denote the corresponding FPE as FPE $(m, 0)$.

ii) Treat $X_{t}$ as a controlled variable with $m$ number of lags, and treat $Y_{t}$ as a manipulated variable as in (2). Compute again the FPE of (2) by varying the order of lags of $Y_{t}$ from 1 to $n$, and determine the order which gives the smallest FPE, say $n$, and denote the corresponding FPE as $\operatorname{FPE}_{\mathrm{X}}(\mathrm{m}, \mathrm{n})^{16}$.

\footnotetext{
${ }^{13}$ The general principle is that smaller lag lengths have smaller variance but run a risk of bias, while larger lags reduce the bias problem but may lead to inefficiency.

${ }^{14}$ Thornton and Batten (1985) show that Akaike's FPE criterion performs well relative to other statistical techniques.

${ }^{15} \mathrm{FPE}_{\mathrm{x}}(\mathrm{m}, 0)$ is computed using the formula: $F P E_{X}(m, 0)=\frac{T+m+1}{T-m-1} \cdot \frac{S S R}{T}$, where $\mathrm{T}$ is the total number of observations and SSR is the sum of squared residuals of OLS regression (1)

${ }^{16} \mathrm{FPEx}(\mathrm{m}, \mathrm{n})$ is computed using the formula: $F P E_{X}(m, n)=\frac{T+m+n+1}{T-m-n-1} \cdot \frac{S S R}{T}$, where $\mathrm{T}$ is the total number of observations and SSR is the sum of squared residuals of OLS regression (2)
} 
iii) Compare $\operatorname{FPE}_{\mathrm{X}}(\mathrm{m}, 0)$ with $\operatorname{FPE}_{\mathrm{X}}(\mathrm{m}, \mathrm{n})$ [i.e., compare the smallest FPE in step (i) with the smallest FPE in step (ii)]. If $\operatorname{FPE}_{\mathrm{X}}(\mathrm{m}, 0)>\mathrm{FPE}_{\mathrm{X}}(\mathrm{m}, \mathrm{n})$, then $Y_{t}$ is said to cause $X_{t}$. If FPE $(\mathrm{m}, 0)<\mathrm{FPE}_{\mathrm{X}}(\mathrm{m}, \mathrm{n})$, then $X_{t}$ is an independent process.

iv) Repeat steps i) to iii) for the $Y_{t}$ variable, treating $X_{t}$ as the manipulated variable.

When $X_{t}$ and $Y_{t}$ are not stationary variables, but are first-difference stationary [i.e., they are I(1) variables] and cointegrated (see Dolado et al., 1990), it is possible to investigate the existence of Granger-causal relationships from $\Delta X_{t}$ to $\Delta Y_{t}$ and from $\Delta Y_{t}$ to $\Delta X_{t}$, using the following error correction models:

$$
\begin{aligned}
& \Delta X_{t}=\alpha_{0}+\sum_{i=1}^{m} \delta_{i} \Delta X_{t-i}+\varepsilon_{t} \\
& \Delta X_{t}=\alpha_{0}+\beta Z_{t-1}+\sum_{i=1}^{m} \delta_{i} \Delta X_{t-i}+\sum_{j=1}^{n} \gamma_{j} \Delta Y_{t-j}+\varepsilon_{t}
\end{aligned}
$$

where $Z_{t}$ is the OLS residual of the cointegrating regression $\left(X_{t}=\mu+\lambda Y_{t}\right)$, known as the error-correction term. Note that, if $X_{t}$ and $Y_{t}$ are $I$ (1) variables, but they are not cointegrated, then $\beta$ in (4) is assumed to be equal to zero.

In both cases [i.e., $X_{t}$ and $Y_{t}$ are $\mathrm{I}(1)$ variables, and they are or are not cointegrated], we can use Hsiao's sequential procedure substituting $X_{t}$ with $\Delta X_{t}$ and $Y_{t}$ with $\Delta Y_{t}$ in steps i) to iv), as well as substituting expressions (1) and (2) with equations (3) and (4). Proceeding in this way, we ensure efficiency since the system is congruent and encompassing (Hendry and Mizon, 1999).

\subsection{Preliminary results}

As a first step, we tested the order of integration of the 10 -year bond yields by means of the Augmented Dickey-Fuller (ADF) tests. Then, following Cheung and Chinn (1997)'s suggestion, we confirmed the results using the Kwiatkowski et al. (1992) (KPSS) tests, 
where the null is a stationary process against the alternative of a unit root. The results, not shown here to save space but available from the authors upon request, decisively reject the null hypothesis of non-stationarity in the first regressions. They do not reject the null hypothesis of stationarity in first differences, but strongly reject it in levels, in the second ones. So, they suggest that both variables can be treated as first-difference stationary ${ }^{17}$.

As a second step, we tested for cointegration between each of the 45 pair combinations ${ }^{18}$ of EMU yields using Johansen (1991, 1995)'s approach. The results suggest ${ }^{19}$ that only for the Greece-Ireland and Greece-Portugal cases does the trace test indicate the existence of one cointegrating equation at (at least) the 5\% level. Therefore, for these two pairs we test for Granger-causality in first differences of the variables, with an error-correction term added [i. e., equations (3) and (4)], whereas for the remaining cases, we test for Granger-causality in first differences of the variables, with no error-correction term added [i. e., equations (3) and (4) with $\beta=0$ ]

\subsection{Empirical results}

The resulting FPE statistics for the whole sample suggest bidirectional Granger-causality in almost all $\operatorname{cases}^{20}$. However, there are some exceptions. We do not find unidirectional Granger-causality in the relationships running from Austria to Ireland, from Finland to France, from France to Ireland and from Greece to Ireland. Nor do we find bidirectional Granger-causality relationships between Austria and Portugal, or between Finland and Greece. However, in order to assess the dynamic Granger-causality between the 90

\footnotetext{
17 These results were confirmed using Phillips-Perron (1998) unit root tests controlling for serial correlation and the Elliott, Rothenberg, and Stock (1996) Point Optimal and Ng and Perron (2001) unit root tests for testing non-stationarity against the alternative of high persistence. These additional results are not shown here to save space, but they are available from the authors upon request.

18 Recall that the number of possible pairs between our sample of ten EMU yield spreads with respect to Germany is given by the following formula $\frac{n !}{r !(n-r) !}=\frac{10 !}{2 !(10-2) !}=45$.

${ }^{19}$ Again, the results are not presented in the interests of space, but are available from the authors upon request.

20 These results are also available from the authors upon request. The results were confirmed using both Wald statistics to test the joint hypothesis $\hat{\gamma}_{1}=\hat{\gamma}_{2}=\ldots=\hat{\gamma}_{n}=0$ in equations (2) or (4) and the Williams-Kloot test for forecasting accuracy (Williams, 1959).
} 
possible EMU yield spreads relationships, we carried out 309,500 rolling regressions using a window of 200 observations $^{21}$ (other authors, Azad et al., (2015) among them, combine the Granger causality with GARCH based estimates, to analyse the time-varying nature of the relationships). The rolling window method uses a fixed length moving window sequentially from the beginning to the end of the sample by adding one observation from ahead and dropping one from behind, where each rolling window subsample includes one observation $^{22}$. In each estimation, we apply Hsiao (1981)'s sequential procedure outlined above to determine the optimum FPE $(\mathrm{m}, 0)$ and FPE $(\mathrm{m}, \mathrm{n})$ statistics in each case We find sub-periods of Granger-causality in all pair-wise relationships, even for those relationships where we found rejection when performing the tests for the whole sample.

After examining the time-varying nature of causal relationships that allows us to detect dynamic investor behaviour in response to news and innovations, we proceed further by identifying sub-periods of significant increase in Granger-causality in order to explore the factors that may have been behind them. To this end, we identify episodes of Grangercausality intensification such as those in which the time-varying Granger-causality indicator is greater than its $5 \%$ bootstrap critical values ${ }^{23}$. Therefore, we look for episodes where there is evidence of an enhancement in the information content of the yield spread series that significantly improves the explanatory power of the future evolution of the other yield spread series that will be associated with episodes of contagion ${ }^{24}$.

\footnotetext{
${ }^{21}$ To the best of our knowledge, there is no statistical method to set the optimal window size; however there is a trade-off between the accuracy of the parameter estimates and the representativeness of the model over the subsample period. On one hand, a small window size reduces heterogeneity and improves the representativeness of parameters, but it may reduce parameter accuracy by increasing the standard errors of estimates. On the other hand, a large window size may improve the accuracy of estimates, but reduces the representativeness of the model. The chosen value of 200 observations is representative of the one used in practice and seems appropriate for our empirical application since it represents $6.36 \%$ of the sample. We have also used a value of 100 observations. The results (not shown here to save space but available from the authors upon request) render the same qualitative conclusions as when 200 observations were used.

22 Since the estimations are based only on the most recent portion of the data, our rolling window approach accommodates parameter variability and is robust to small samples and presence of multiple structural breaks and nonlinearities, providing evidence of existence or otherwise of temporal causal relationship (in-sample predictability over time) between the variables under study.

${ }^{23}$ We perform formal tests to evaluate whether the series have the same mean during the detected episodes and the rest of the observations. The results of these tests (not shown here, but available from the authors upon request) strongly reject the null hypothesis of equal mean across sub-samples, and provide additional support for the presence of increased Granger-causality.

${ }^{24}$ Using the framework for grading the strength of the Granger-causality relationship proposed by Atukeren (2005) we obtain the same classification of episodes of causality intensification. Atukeren (2005)'s framework uses Postkitt and Tremayne (1987)'s posterior odds ratio test and Jeffreys (1961)'s Bayesian concept of grades of evidence.
} 
The graphs in Figures 2 suggest that these episodes are concentrated after the inception of the EMU in 1999-2000, and matching the Global Financial Crisis that began in October 2008 with Lehman Brothers collapse. Specifically, Figures 2a to 2d represent the number of causality intensification episodes detected within peripheral countries (Figure 2a), from peripheral to central countries (Figure 2b), within central countries (Figure 2c), and from central to peripheral countries (Figure 2d). In general, the figures indicate that contagion episodes preceded the outburst of the Global Financial Crisis. Indeed, in most of the cases, causality intensification is detected from March 2008, and reached a peak in 2011. These results signal that our empirical strategy to detect contagion episodes provides some useful information about the examined countries' vulnerability to crises.

\section{[Insert Figures 2 here]}

\subsection{Alternative empirical results ${ }^{25}$}

In order to examine how our empirical results change when we adopt the methods used in prior studies that take into account the time-varying nature of the relationships, we follow previous contributions by Celik (2012), Lean and Tuan (2013), Azad et al. (2015) and Hou and Li (2016) and use Engle's (2002) Dynamic Conditional Correlation (DCC) model. The time-varying correlation estimated from this model indicates market integration. Markets become more integrated when the conditional correlation increases over time ( $\mathrm{Yu}$ et al., 2010). This model is able to capture the volatility correlation between two markets, either directly through its conditional variance or indirectly through its conditional covariances. The model is also able to examine the volatility spillover from one market to another market, providing insight on both markets' synchronization and volatility clustering in financial series. The DCC has two stages. In the first step, the GARCH parameters are

\footnotetext{
${ }^{25}$ We are grateful to an anonymous referee for suggesting this analysis.
} 
estimated. In the second step, the conditional correlations are estimated using the DCC method as follows:

$$
H_{t}=D_{t} R_{t} D_{t}
$$

where $H_{t}$ is a kxk conditional covariance matrix, $R_{t}$ is the conditional correlation matrix, and $D_{t}$ is diagonal matrix of time-varying standard deviations.

The likelihood of the DCC estimator is:

$$
L=-0.5 \sum_{t=1}^{T}\left(k \log (2 \pi)+2 \log \left(\left|D_{t}\right|\right)+\log \left(\left|R_{t}\right|\right)+\varepsilon_{t}^{\prime} R_{t}^{-1} \varepsilon_{t}\right) .
$$

The volatility $\left(D_{t}\right)$ and the correlation $\left(R_{t}\right)$ components may vary, thus the estimation process is achieved in two steps.

Firstly the volatility $\left(L_{v}\right)$ is maximized:

$$
L_{v}=-0.5 \sum_{t=1}^{T}\left(k \log (2 \pi)+\log \left(\left|D_{t}\right|^{2}\right)+r_{t}^{\prime} D_{t}^{-2} r_{t}\right)
$$

then the correlation $\left(L_{\imath}\right)$ is maximized:

$$
L_{c}=-0.5 \sum_{t=1}^{T}\left(\log \left(\left|R_{t}\right|\right)+\varepsilon_{t}^{\prime} R_{t}^{-1} \varepsilon_{t}-\varepsilon_{t}^{\prime} \varepsilon_{t}\right)
$$

Engle (2002) proposed a two-step estimation. The DCC model is estimated by a two-step procedure: a) in the first step univariate GARCH models are fitted for each assets' returns and estimates of their variances are thus obtained; b) the returns are filtered out of the GARCH effect (degarched returns) by dividing by their estimated standard deviations and then are used to estimate the dynamics of correlation, $\varepsilon_{i t}=r_{i t} / \sqrt{h_{i t}}$. In the second step, the standardized residuals are used to estimate the time-varying correlation matrix.

The model developed by Engle (2002) has the following non-linear GARCH specification for the conditional correlation: 


$$
Q_{t}=(1-a-b) \bar{Q}+a \varepsilon_{t-1} \varepsilon_{t-1}^{\prime}+b Q_{t-1}
$$

where $Q_{t}=\left(q_{i j, t}\right)$ is a $n \times n$ symmetric positive definite matrix, $a$ and $b$ are nonnegative scalars such as $a+b<1$, a is the news coefficient and $b$ is the decay coefficient. $\bar{Q}=E\left(\varepsilon_{t} \varepsilon_{t}^{\prime}\right)$ is the unconditional variance matrix of the standardized residuals (the unconditional correlation). The conditional correlations $q_{i j, t}$ are time-varying and follow a structure similar to a GARCH $(1,1)$ model.

For ensuring a conditional correlation between -1 and +1 , by normalization the correlation can be expressed $\rho_{i j, t}=q_{i j, t} / \sqrt{q_{i i . t} q_{j j . t}}$. The correlations are obtained by transforming this to:

$$
R_{t}=\left(\operatorname { d i a g } ( Q _ { t } ) ^ { - 0 . 5 } Q _ { t } \left(\operatorname{diag}\left(Q_{t}\right)^{-0.5}\right.\right.
$$

where $\left(\operatorname{diag}\left(Q_{t}\right)^{0.5}\right.$ is a diagonal matrix of the square root of the diagonal elements of $Q_{t}$.

Based on the estimated pair-wise dynamic conditional correlations, we associate episodes of contagion with monthly average values greater than 0.7 , as an increase in conditional correlations can be signalling an intensification of the interdependence and a synchronised responses to shocks. Figures 3 report the results.

\section{[Insert Figures 3 here]}

A striking feature of these figures is that the resulting number of contagion episodes is quite jagged and they are not always higher during crisis times than during tranquil times.

If we compare the contagion episodes detected using the dynamic Granger causality methodology (Figures 2) and the DCC-GARCH model (Figures 3), it can be observed that with the exception of the episodes detected from peripheral to central countries (where we find disagreement in $70 \%$ of the cases and agreement in only $30 \%$ of them), in the rest of the groups we can find either a concordance or a discrepancy in the contagion episodes 
detected using one or the other methodology (the percentage is close to $50 \%$ in both cases). However, it is noticeable that in the four groups of relationships, around $30 \%$ of the disagreements represent underestimation of contagion by the DCC-GARCH model in times of crisis (from August 2009 till the second semester of 2012). It is clear from this analysis that our empirical strategy to identify contagion episodes yields more accurate indicators of the spread of market disturbances than the DCC-GARCH model might. Gaining a better understanding of the reasons for the observed differences in identifying contagion episodes depending on the applied methodology is an important task for future research. Meanwhile, recall that the main limitation of the standard DCC model is the assumption that the conditional correlations follow the same dynamic structure which might not be realistic in empirical work (Caporin and McAleer, 2013) in contrast to our econometric strategy where different dynamics may be assumed ${ }^{26}$. This limitation could account for the observed occurrences of false positives (results that indicate that a given condition is present when it actually is not) derived from the estimated DCC-GARCH models.

\subsection{A closer look at the empirical results}

Since our methodology to detect contagion episodes seems to present better performance, Figure 4 takes a closer look to the empirical results by plotting daily contagion episodes within all EMU countries using Granger-causality intensification jointly with the evolution of yield spreads.

[Insert Figure 4 here]

\footnotetext{
${ }^{26}$ Furthermore, if the data have structural breaks, the conditional correlation models may lead to incorrect estimation of the risk, while our econometric strategy can be used to detected structural breakpoints and to incorporate them into the analysis (Gómez-Puig and Sosvilla-Rivero, 2014). Also, the DCC model is limited to a small number of assets, while our econometric strategy can be generalised for a large number of assets.
} 
It can be observed that during the Global Financial Crisis, contagion episodes detected within all EMU countries can be clustered into three phases ${ }^{27}$. The first phase, which can still be defined as a pre-crisis period, begins in March 2008 when, after a short respite following the takeover of Bear Stearns on 16 March 2008, financial asset prices came under renewed pressure and ends in March 2009. A distinctive feature of this period was an increased investor focus on signs that the US recession had spilled over to other major economies, triggering a synchronized economic downturn ${ }^{28}$. Besides, after Lehman Brothers collapse in mid-September 2008, the crisis was mainly marked by concerns about its repercussions, since the balance sheets of banks all around the globe indicated exposure to their assets. Therefore, policy action was implemented on an international scale as governments sought to support market functioning and to cushion the blow of rapid economic contraction. In the European context, the ECB announced liquidity to support European Banks ${ }^{29}$, while the European Commission adopted the European Recovery Plan and allowed governments to implement measures to bailout banks.

The second phase covers the period September 2009-July 2010. At the beginning of this period, the newly elected Greek government announced that the country's budget deficit was much larger than previously reported, marking the beginning of the sovereign debt crisis in Europe. Moreover, during this period, the first rescue package was put in place in Greece (May 2010) and fears that Greece's debt crisis would spread to EMU peripheral countries were very strong.

Finally, the third and deepest phase of contagion episodes started at the end of October 2010 and ended in July 2012. This phase was a time of real turbulence in EMU sovereign debt markets since the crisis had already spread to other EMU countries and Ireland (November 2010) and Portugal (April 2011) also needed to be bailed out to stay afloat. In

\footnotetext{
${ }^{27}$ Following the Bank for International Settlements, Singh et al. (2016) divide the Global Financial Crisis into eight different episodes and broadly explain the main events in each of them.

${ }^{28}$ Indeed, the euro area officially entered recession in the last quarter of 2008 when its GDP fell $-2.1 \%$.

${ }^{29}$ In September 2008 the Irish government already guaranteed all the deposits/debts of the country's banks.
} 
this context of financial distress and huge liquidity problems (we should recall that Italy was in the middle of a political crisis and that main rating agencies lowered the ratings not only of peripheral countries but of Austria and France as well), the European Central Bank responded forcefully by implementing (along with other central banks) nonstandard monetary policies, i.e., policies beyond setting the refinancing rate ${ }^{30}$. However, in March 2012 the second rescue package to Greece was approved and in June 2012 Spain requested financial assistance to recapitalize its banking sector. This was the backdrop to the ECB's President Mario Draghi's statement that he would do "whatever it takes to preserve the euro". So, the third phase finishes after that statement in July 2012, since from them the healing effects of Draghi's words can be clearly observed in EMU sovereign debt markets.

It is noticeable that during the third phase, when euro debt crisis was going through its worst time, contagion episodes registered an important increase compared to the other two, reaching their peak during January-May 2011. Therefore, results presented in Figure 4, that plots the time-evolution of these causality intensification episodes within all EMU countries jointly with yield spreads evolution, not only provide evidence of the "forward looking" nature of our indicator of contagion (it precedes the crisis outbreak), but also of a reinforcement in the interconnection between debt markets during times of huge distress. Indeed, the first phase of contagion episodes (2008:03-2009:03) leads the start of a number of successive increases in yield spreads, being these increases higher, the higher is the number of episodes detected. This feature is related to the fact that our methodology is based on predictability and could be capturing the changing market participants' expectations and mood. Finally, it is also notable that, in times of crisis, contagion episodes are more frequent when the triggering countries in the causal relationships are peripheral ( $57 \%$ of the total, see Figures $2 \mathrm{a}$ and $2 \mathrm{~b}$ ) rather than central.

\footnotetext{
${ }^{30}$ In particular, the ECB's principal means of intervention were the so-called long term refinancing operations (LTRO). In November 2011 and March 2012, the ECB allotted to banks an amount close to 500 billion Euros for a three-year period.
} 


\section{Determinants of episodes of Granger-causality intensification}

\subsection{Econometric methodology}

Once the episodes of causality intensification have been detected based in our empirical strategy, we use logit models to analyse their determinants. We define a new dependent variable $\left(y_{i t}\right)$ that takes the value one if we have detected such episode and zero otherwise.

The goal is to quantify the relationship between a set of instruments $\left(x_{i t}\right)$ characterizing the two countries involved in an episode of Granger-causality intensification and the probability of occurrence of such event $\left(y_{i t}\right)$.

To this end, we adopt a specification designed to handle the particular requirements of binary dependent variables. Suppose that we model the probability of observing a value of one as:

$$
\operatorname{Pr}\left(y_{i t}=1 \mid \mathrm{x}_{\mathrm{it}}, \beta\right)=1-\left(\frac{e^{-x_{i t}^{\prime} \beta}}{1+e^{-x_{i t}^{\prime} \beta}}\right)=\left(\frac{e^{x_{i t}^{\prime} \beta}}{1+e^{x_{i t}^{\prime} \beta}}\right)
$$

which is based upon the cumulative distribution function for the logistic distribution.

In order to establish the relevant determinants of the episodes of the Granger causality intensification, we employ a data-based method for obtaining parsimony representation of the data generation process: the general-to-specific approach (Hendry, 1995). General-tospecific modelling seeks to mimic reduction by commencing from a general congruent specification that is simplified to a minimal representation consistent with the desired criteria and the data evidence. Starting from a general congruent model that contains all the effects likely to be relevant (see Appendix A), standard testing procedures eliminate statistically-insignificant variables, with diagnostic tests checking the validity of reductions, ensuring a congruent final selection that renders a parsimonious and interpretable econometric model. 


\subsection{Empirical evidence}

Given that the instruments used as independent variables have been constructed with a monthly frequency, we also need to compute the dependent variable in the logit models on a monthly basis. We calculate the monthly data by assigning a value of 1 if at least for half of the month there is evidence of intensification in the interconnection between yield spreads, and a value of 0 otherwise.

As mentioned before, our empirical analysis starts with a general unrestricted statistical model including all explanatory variables to capture the essential characteristics of the underlying dataset, testing it down by eliminating statistically insignificant variables, and checking the validity of the reductions at each stage to ensure congruence of the finally selected model ${ }^{31}$. We have also considered the possibility of both individual-specific effects (in each pair-wise relationship) and time-specific effects, by incorporating dummy variables, testing the joint significance of these dummies separately and once they are taken together. In Table 3 we report the final results of the logit models estimated by maximum likelihood for five groups of countries: the first correspond to causal relationship intensification episodes within pairs of all EMU countries, the second within pairs of peripheral countries, the third from peripheral to central countries, the fourth within central countries, and lastly, the fifth from central to peripheral countries ${ }^{32}$. The $z$-statistics in that table are based on robust standard errors computed using the Huber-White quasi-maximum likelihood method. As can be seen, all the estimated coefficients shown in Table 3 are significant at the $1 \%$ level, and the individual and time dummies are jointly significant for the relationships from peripheral to central countries, and in those between central countries,

\footnotetext{
31 Note that this commonly used approach is a process driven by the data. We have also explored the possibility of adopting an alternative theory-driven approach using a specific-to-general modeling process by estimating equation (5) with each potential category of determinants having only one representative variable, leading to a multiplicity of models by the successive incorporation of additional variables. Interestingly, this alternative approach that explicitly acknowledges that there may be several models that are generated by the same data set (Hendry, 1995) renders final specifications that are very close to the one obtained from the general-to-specific approach, giving further support to our results.

32 The results are very similar for Probit models run on the same data.
} 
while in the other three cases we only find that the individual dummies are statistically significant.

The sign of the regression parameters can be immediately interpreted as determining whether the latent variable increases with the regressor. As can be seen, most of the estimated coefficients are positive, suggesting that an increase in the variable necessarily increases the probability of being in the contagion category $\left(y_{i t}=1\right)$. The converse is true for the negative sign coefficients associated with the consumer confidence indicator, the net position towards the rest of the world, and the market liquidity ${ }^{33}$.

In binary models, estimated coefficients cannot be interpreted as the marginal effect on the dependent variable. Therefore, to gain further insights in the influence of the explanatory variables, in Table 3 we also show the associated marginal effects to compare their relative impacts. These marginal effects measure the influence of a unit change in a given explanatory variable on the probability of pair-wise Granger-causality intensification, holding all the other variables constant and, following Bartus (2005) have been computed at their average values ${ }^{34}$.

[Insert Table 3 here]

The empirical evidence presented in Table 3 does not support the occurrence of either "fundamentals-based" or "pure" contagion in euro area countries, but it suggests that a mixture of the two might have taken place. Specifically, when examining all pair-wise relationships (see column 1), we find that not only some of the variables which capture both local and regional market sentiment are statistically significant, but that some local

\footnotetext{
${ }^{33}$ Recall that an increase in consumer confidence may lead to a rise in investor confidence, so it seems reasonable to expect a negative relationship between it and the probability of occurrence of a contagion episode. Regarding the current-account-balance-to-GDP ratio, which is the instrument used as a proxy of the net position of the country towards the rest of the world, since this variable is defined as the difference between exports and imports, an increase would have a negative effect on the probability of contagion. Finally, given that our measure of market liquidity is the overall amount of outstanding debt and that liquidity premium decreases with market size, one would expect a negative impact between this variable and contagion.

${ }^{34}$ Nevertheless, the direction of the effect of a change in any instrument depends only on the sign of the coefficient estimated: positive values imply that an increase in a given instrument will raise the probability of an increase in pair-wise Granger causality, while negative values indicate the opposite.
} 
macroeconomic variables together with the instrument which gauges financial linkages are also relevant.

These findings qualify and improve previous evidence presented in the literature. Dungey and Gajurel (2014) state that the two types of contagion are not necessary mutually exclusive; Ludwig (2014) points out that "pure" contagion effects are likely to be overstated when changes in common risk factors are not controlled for; Philippas and Siriopoulos (2013) point out that international portfolios pay attention to cross-market correlation dynamics within the Eurozone, based not only on their excess macroeconomic and fiscal performances but also driven by behavioural reasons; Arghyrou and Kontonikas (2012) find a marked shift in market pricing behaviour from a pre-crisis 'convergence-trade' model before August 2007 to one driven by both macro-fundamentals and international risk thereafter; whilst Beirne and Fratzscher (2013), who identify "fundamental-based contagion" with a reassessment of fundamentals in times of crisis, document that the prime explanation for the sharp sovereign risk increase during the EU debt crisis was due to fundamental rather than to pure contagion (unlike them, in this paper we follow Goldstein (1998) or Masson (1999) and consider sudden shifts in market confidence and/or expectations that may lead to a reconsideration of unchanged fundamentals as important factors causing "pure contagion" $\left.{ }^{35}\right)$.

Indeed, recent European events have encouraged a new discussion of contagion. Differently from previous crises, in which the country responsible for spreading the shock was relatively clear, in the euro area sovereign debt crisis several peripheral countries entered a fiscal crisis at roughly the same time. Actually, when a group of countries share an exchange rate agreement (a common currency in the case of the euro area countries), crises tend to be clustered. It seems reasonable that, since the economic fundamentals of EMU countries are interconnected by their cross-border flows of goods, services, and

${ }^{35}$ See Section 2.1 
capital, other variables beyond herding behaviour or sudden shifts in market confidence might also be at the origin of crisis propagation.

Nevertheless, we observe some disparities when analysing crisis transmission from the different groups of countries, peripheral or central. In particular, it can be observed that the nearest that crisis transmission is to the definition of "pure contagion" is when the causal relationship is from peripheral to central countries. In this case, local market sentiment's variables represent $40 \%$ of the drivers of an abnormal increase in the intensity of causal relationships (see column 3). However, it is noticeable that, in all the cases, crisis transmission seems to be explained by idiosyncratic variables (either market sentiment or fundamental, who account for more than $75 \%$ of the total significant variables) rather than by shifts in common regional variables.

Looking across the columns ${ }^{36}$, we see that, with regard to the variables measuring local market sentiment, we find a positive and significant effect for the stock-market volatility, the index of the fiscal stance and the credit rating (as expected, the consumer confidence indicator presents a negative sign). Notice that the marginal effects of the variable capturing the fiscal stance are much higher than those associated with other local market sentiment variables. As for the local macrofundamentals, our results suggest a negative impact on contagion for both the net position towards the rest of the world and the market liquidity variable, and a positive effect for the country growth potential (proxied by the unemployment rate), the competitiveness (captured by the inflation rate) and the fiscal position (measured by the debt/GDP or the deficit/GDP ratios). The estimated marginal effect of the domestic inflation rate is particularly high in the relationships where central countries are the triggers and in the relationships from peripheral to central countries. In relation to indicators of regional market sentiment, we detect that the credit spread in

\footnotetext{
${ }^{36}$ We summarize the results by pointing out the main regularities. The reader is asked to browse through Table 3 to find evidence for a particular group of countries of her/his special interest.
} 
European corporate bond market plays a decisive role in contagion episodes within either peripheral or central countries, while the European 5-year CDS index in the non-financial sectors $\left(\right.$ ITRAXX $_{\mathrm{NF}}$ ) is especially relevant when examining relationships when central countries are the triggers. The variable euro instability which reflects the market expectation of the probability that at least one euro area country would have left the currency union at the end of 2013 is found to be positive and statistically significant in all cases, showing higher marginal effects than those associated with other regional market sentiment variables. As regards the potential role of financial linkages in the contagion episodes, we find a significant effect for the variable measuring cross-border banking linkages when analysing the whole sample, and the causal relationships from peripheral to central countries, supporting the close interconnection between the banking and the sovereign sectors. Nevertheless, it should be noticed that the marginal effect of this last variable is very small.

Interestingly, none of variables measuring global market sentiment or regional macroeconomic variables was found to be statistically significant. With respect to the latter result, the fact that the dependent variable used in the analysis is the yield spread over the German bund might have cancelled out all common regional macroeconomic effects that might have adversely affected the economic fundamentals of several economies simultaneously, since they may have been captured by the evolution of the German yield. As for the global market sentiment, the result suggests that shifts in local or regional rather than global market sentiment are behind euro area debt crisis transmission. These results are in line with Gómez-Puig and Sosvilla-Rivero (2014) who explore the breakpoints in EMU yield evolution and find that not only are half of the breakpoints directly connected to the euro sovereign debt crisis, but that $63 \%$ of them occur after November 2009 (once Papandreou's government announced the Greece's distressed debt position). Additionally, the absence of global market sentiment in the final regressions could also suggest that 
EMU has effectively acted as a true system, in which common conditions have had priority over global ones, and where only real differences (at least as perceived by market participants) could have explained the dissimilar evolution in sovereign yield spreads.

Finally, in Table 3 we also report the McFadden pseudo- $\mathrm{R}^{2}$ statistic as a measure of goodness of the fit. As can be seen, it ranges from 0.3535 to 0.4096 , suggesting the relative success of the estimated logit regression models in predicting the values of the dependent variable within the sample when set against previous work with these models. Note that $\chi^{2}$ and $\log$ likelihood diagnostic statistics are also satisfactory. As a further test to evaluate how well our estimated models account for the observations, in Table 3 we also present the proportion of outcomes correctly predicted by the estimated models, denoted as Count $\mathrm{R}^{2}$. As can be seen, it ranges from 0.6552 to 0.7779 , which can be considered a fairly good result.

\section{Concluding remarks}

In this paper, we have empirically investigated whether the transmission of the recent crisis in euro area sovereign debt markets was due to pure or fundamentals-based contagion. To this end, we have examined the behaviour of EMU sovereign bond yield spreads with respect to the German bund for a sample of both central (Austria, Belgium, Finland, France and the Netherlands) and peripheral countries (Greece, Ireland, Italy, Portugal and Spain) from January 1999 to December 2012.

Using daily data, we first adopted an eclectic approximation and applied a dynamic approach to analyse the evolution of the degree of Granger-causality within the 90 pairs of sovereign bond yield spreads in our sample. We aimed to detect episodes of significantly increased causality between them to capture the strength of transmission, which we associate with contagion. As in every empirical analysis, the results must be taken with caution since they are based on a set of countries over a certain period and on a given 
econometric methodology. Nevertheless, our findings suggest that these episodes are concentrated just after the inception of the EMU in 1999-2000, and matching the Global Financial Crisis (an important peak is reached in 2011). Moreover, our identified contagion episodes preceded the outburst of the crisis since they are detected from March 2008. This feature is related to the fact that our methodology is based on predictability and could be capturing the changing market participants' expectations and mood, becoming a good forward-looking predictor of the euro debt crisis unfolding. Compared to previous work that focused only DCC-GARCH models, this new methodology identifies substantially different contagion episodes, yielding more accurate and sensible indicators of the spread of market disturbances.

We then used a logit model with monthly data to assess whether a set of variables proposed in the theoretical and empirical literature measuring market sentiment (either global, regional and local), as well as macrofundamentals (both regional and local) and financial linkages have a significant influence in the occurrence of the detected episodes. The findings underline the importance of both variables proxying market sentiment and macrofundamentals in determining contagion outcomes. Therefore, sovereign risk premium increase in the euro area during the European sovereign crisis was not due only to deteriorated debt sustainability in member countries; nor can it be explained only by herding behaviour or sudden shifts in market confidence and expectations. Nevertheless, our analysis highlights the relative importance of market participants' perceptions in contagion episodes from peripheral to central countries. We think that our empirical evidence supporting that both types of contagion took place during the European sovereign debt crisis is sensitive, since the sudden loss of market confidence, brought about by the financial crisis, might have enlarged the effects of deteriorated fundamentals over yield spreads. 
We consider that our results may have some practical implications for investors and policymakers regarding hedging and investing behaviour and choices, and may provide theoretical insights for academic scholars interested in the behaviour of sovereign debt markets and for those scholars interested in asset international pricing models. Additionally, our methodology can be used as a tool to provide information regarding the factors underlying crisis transmission and related risks, helping to design appropriate policies in advance for avoiding any impending crisis. 


\section{Appendix A: Definition of the explanatory variables in the logistic regressions and data sources}

\section{A.1. Variables that measure local market sentiment.}

\begin{tabular}{|c|c|c|}
\hline Variable & Description & Source \\
\hline Stock Returns & $\begin{array}{l}\text { Differences of logged stock indices prices of the last and the } \\
\text { first day of the month for each country. }\end{array}$ & Datastream \\
\hline Stock Volatility & $\begin{array}{l}\text { Monthly standard deviation of the daily returns of each } \\
\text { country's stock market general index }\end{array}$ & Datastream \\
\hline $\begin{array}{l}\text { Index of Economic Policy Uncertainty } \\
\text { (Germany, France, Italy, and Spain) }\end{array}$ & $\begin{array}{l}\text { This index draws on the frequency of newspaper references to } \\
\text { policy uncertainty and was created by Baker et al., } 2013 \text {. }\end{array}$ & www.policyuncertainty.com \\
\hline Index of the Fiscal stance & $\begin{array}{l}\text { This indicator compares a target level of the debt-GDP ratio at } \\
\text { a given point in the future with a forecast based on the } \\
\text { government budget constraint. It was created by Polito and } \\
\text { Wickens }(2011,2012) \text {. Monthly data were linearly interpolated } \\
\text { from yearly observations for the available data: 1999-2011 }\end{array}$ & Provided by the authors. \\
\hline Consumer Confidence Indicator & $\begin{array}{l}\text { This index is built up by the European Commission which } \\
\text { conducts regular harmonised surveys to consumers in each } \\
\text { country. }\end{array}$ & $\begin{array}{l}\text { European Commission (DG } \\
\text { ECFIN) }\end{array}$ \\
\hline Rating & $\begin{array}{l}\text { Credit rating scale built up from Fitch, Moody's, S\&P ratings } \\
\text { for each country. }\end{array}$ & Bloomberg \\
\hline
\end{tabular}

A.2. Variables that measure regional market sentiment.

\begin{tabular}{|c|c|c|}
\hline Variable & Description & Source \\
\hline Stock Returns & $\begin{array}{l}\text { Differences of logged stock indices (Eurostoxx-50) prices of } \\
\text { the last and the first day of the month for each country. }\end{array}$ & Yahoo-finance \\
\hline Stock Volatility (VSTOXX) & $\begin{array}{c}\text { Eurostoxx-50 implied stock market volatility index. Monthly } \\
\text { average of daily data. }\end{array}$ & www.stoxx.com \\
\hline $\begin{array}{l}\text { Index of Economic Policy Uncertainty } \\
\text { (Europe) }\end{array}$ & Baker et al., 2013. & www.policyuncertainty.com \\
\hline $\begin{array}{c}\text { Index of the Fiscal stance } \\
\text { (Europe) }\end{array}$ & $\begin{array}{l}\text { Polito and Wickens }(2011,2012) \text {. Monthly data were linearly } \\
\text { interpolated from yearly observations for the available data: } \\
1999-2011 .\end{array}$ & Provided by the authors. \\
\hline $\begin{array}{l}\text { Consumer Confidence Indicator } \\
\text { (Eurozone) }\end{array}$ & European Commission & $\begin{array}{l}\text { European Commission (DG } \\
\text { ECFIN) }\end{array}$ \\
\hline Credit Spread & $\begin{array}{l}\text { Difference between the yields of the iBoxx indices } \\
\text { containing BBB-rated European corporate bonds against the } \\
\text { yields of the respective iBoxx index of AAA-rated European } \\
\text { corporate bonds. Monthly average of daily data. }\end{array}$ & Datastream \\
\hline $\begin{array}{l}\text { ITRAXX }_{\text {FIN }} \\
\text { ITRAXX }_{\mathrm{NF}}\end{array}$ & $\begin{array}{c}\text { European 5-year CDS index in the financial and non- } \\
\text { financial sectors: 2010:9-2012:12. } \\
\text { Monthly average of daily data. }\end{array}$ & Bloomberg \\
\hline $\begin{array}{l}\text { EIRVIX-1Y } \\
\text { EIRVIX-10Y }\end{array}$ & $\begin{array}{l}\text { 1-year and 10-year interest rate volatility index for the } \\
\text { Eurozone based on the implied volatility quotes of caps } \\
\text { (floors). This index was created by López and Navarro } \\
\text { (2013) for the period 2004:1-2012:4. }\end{array}$ & Provided by the authors. \\
\hline Euro Instability & $\begin{array}{l}\text { Market expectation of the probability that at least one Euro } \\
\text { area country will have left the currency union at the end of } \\
\text { 2013, built up by Klose and Weigert (2012) for the period } \\
\text { 2010:8-2012:8. Monthly average of daily data. }\end{array}$ & Provided by the authors. \\
\hline Euro area default risk & $\begin{array}{l}\text { Probability of two or more credit events, calculated by Lucas } \\
\text { et. al. (2013): 2008:1-2012:12 }\end{array}$ & Provided by the authors. \\
\hline
\end{tabular}

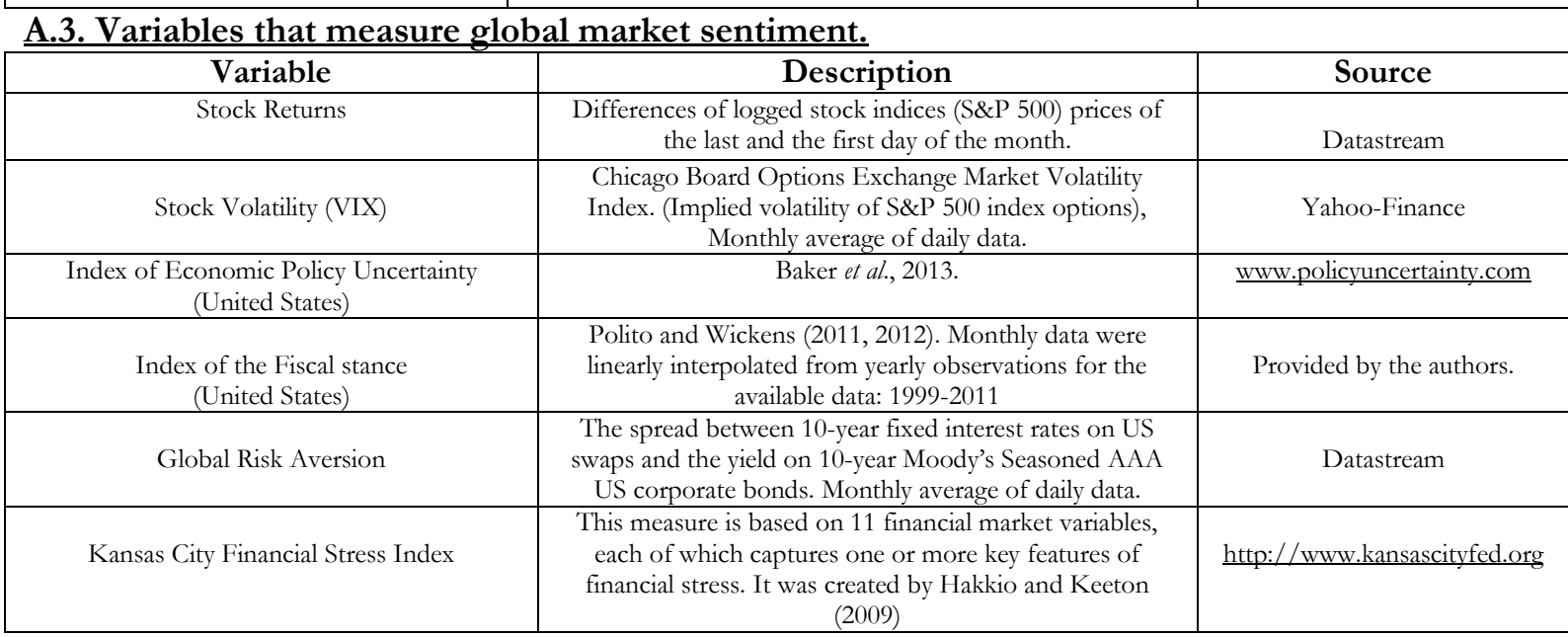


A.4. Variables that measure local macrofundamentals.

\begin{tabular}{|c|c|c|}
\hline Variable & Description & Source \\
\hline $\begin{array}{l}\text { Net position vis-à-vis } \\
\text { the rest of the world }\end{array}$ & $\begin{array}{c}\text { Current-account-balance-to-GDP } \\
\text { Monthly data are linearly interpolated from quarterly } \\
\text { observations. }\end{array}$ & OECD \\
\hline Growth potential & Unemployment rate & Eurostat \\
\hline Competitiveness & Inflation rate. HICP monthly interannual rate of growth & Eurostat \\
\hline Fiscal Position & $\begin{array}{c}\text { Government deficit-to-GDP and Government debt-to-GDP. } \\
\text { Monthly data are linearly interpolated from quarterly } \\
\text { observations. }\end{array}$ & Eurostat \\
\hline Market liquidity & $\begin{array}{c}\text { Domestic Debt Securities. Public Sector Amounts Outstanding } \\
\text { (billions of US dollars) } \\
\text { Monthly data are linearly interpolated from quarterly } \\
\text { observations. }\end{array}$ & BIS Debt securities statistics. Table 18 \\
\hline Bank's debt & $\begin{array}{c}\text { Banks' debt-to-GDP. } \\
\text { Monthly data are linearly interpolated from quarterly } \\
\text { observations for the GDP. }\end{array}$ & $\begin{array}{l}\text { ECB's Monetary Financial Institutions } \\
\text { balance sheets and own estimates. } \\
\text { GDP has been obtained from Eurostat }\end{array}$ \\
\hline $\begin{array}{c}\text { Non-financial } \\
\text { corporation's debt }\end{array}$ & $\begin{array}{c}\text { Non-financial corporations' debt-to-GDP. } \\
\text { Monthly data are linearly interpolated from quarterly } \\
\text { observations for the GDP. }\end{array}$ & $\begin{array}{l}\text { ECB's Monetary Financial Institutions } \\
\text { balance sheets and own estimates. } \\
\text { GDP has been obtained from Eurostat }\end{array}$ \\
\hline Household's debt & $\begin{array}{c}\text { Households' debt-to-GDP of country. } \\
\text { Monthly data are linearly interpolated from quarterly } \\
\text { observations for the GDP. }\end{array}$ & $\begin{array}{l}\text { ECB's Monetary Financial Institutions } \\
\text { balance sheets and own estimates. } \\
\text { GDP has been obtained from Eurostat }\end{array}$ \\
\hline
\end{tabular}

A.5. Variables that measure regional macrofundamentals.

\begin{tabular}{|c|c|c|}
\hline Variable & Description & Source \\
\hline $\begin{array}{l}\text { Net position vis-à-vis } \\
\text { the rest of the world. }\end{array}$ & $\begin{array}{c}\text { Current-account-balance-to-GDP } \\
\text { Monthly data are linearly interpolated from quarterly } \\
\text { observations. }\end{array}$ & OECD \\
\hline Growth potential & Unemployment rate & Eurostat \\
\hline Competitiveness & Inflation rate. HICP monthly interannual rate of growth & Eurostat \\
\hline Fiscal Position & $\begin{array}{c}\text { Government deficit-to-GDP and Government debt-to-GDP. } \\
\text { Monthly data are linearly interpolated from quarterly } \\
\text { observations. }\end{array}$ & Eurostat \\
\hline Market liquidity & $\begin{array}{c}\text { Domestic Debt Securities. Public Sector Amounts Outstanding } \\
\text { (billions of US dollars) } \\
\text { Monthly data are linearly interpolated from quarterly } \\
\text { observations. }\end{array}$ & BIS Debt securities statistics. Table 18 \\
\hline
\end{tabular}

A.6. Variables that measure financial linkages.

\begin{tabular}{|c|c|c|}
\hline Variable & Description & Source \\
\hline Foreign claims on bank debt & $\begin{array}{c}\text { Foreign bank claims on banks debt-to-GDP. } \\
\text { Monthly data are linearly interpolated from quarterly } \\
\text { observations. }\end{array}$ & $\begin{array}{l}\text { BIS Consolidated banking statistics. Table } \\
\text { 9C. GDP has been obtained from the } \\
\text { OECD. }\end{array}$ \\
\hline Foreign claims on public debt & $\begin{array}{l}\text { Foreign bank claims on government debt-to-GDP. } \\
\text { Monthly data are linearly interpolated from quarterly } \\
\text { observations. }\end{array}$ & $\begin{array}{l}\text { BIS Consolidated banking statistics. Table } \\
\text { 9C. GDP has been obtained from the } \\
\text { OECD }\end{array}$ \\
\hline $\begin{array}{l}\text { Foreign claims on non-financial } \\
\text { private debt. }\end{array}$ & $\begin{array}{l}\text { Foreign bank claims on non-financial private debt- } \\
\text { to-GDP. Monthly data are linearly interpolated from } \\
\text { quarterly observations. }\end{array}$ & $\begin{array}{l}\text { BIS Consolidated banking statistics. Table } \\
\text { 9C. GDP has been obtained from the } \\
\text { OECD. }\end{array}$ \\
\hline Cross-border banking linkages & $\begin{array}{l}\text { Percentage of the total foreign claims on country } \\
\text { XX held by country YY's banks }\end{array}$ & $\begin{array}{l}\text { BIS Consolidated banking statistics. Table } \\
\text { 9D and own estimates. }\end{array}$ \\
\hline
\end{tabular}

\section{Acknowledgements}

The authors thank the insightful comments of two anonymous referees and the Editor that have helped to substantially improve this paper. We are also very grateful to Analistas Financieros Internacionales for kindly providing the credit rating and the European 5-year CDS indices datasets. We also thank the following authors who provided datasets built up by themselves: Scott R. Baker, Nicholas Bloom, and Steven J. Davis; Craig S. Hakkio and William R. Keeton; Jens Klose and Benjamin Weigert; Raquel López and Eliseo Navarro; André Lucas, Bernd Schwaab and Xin Zhang; and Vito Polito and Michael R. Wickens. Thanks are also due to Maria del Carmen RamosHerrera for research assistance. This paper is based upon work supported by the Government of Spain under grant numbers ECO2011-23189 and ECO2013-48326. Simón Sosvilla-Rivero thanks the Universitat de Barcelona and RFA-IREA for their hospitality. Responsibility for any remaining errors rests with the authors. 


\section{References}

Akaike, H., 1974. A new look at the statistical model identification. IEEE Transactions on Automatic Control 19, 716-723

Allen, F.; Beck; T., Carletti; E., Lane; P. L., Schoenmaker, D., Wagner, W., 2011. Crossborder Banking in Europe: Implications for Financial Stability and Macroeconomic

Policies. Centre for Economic Policy Research, London.

Akerlof, G. A., Shiller, R. J. , 2009. Animal Spirits. Princeton University Press, Princeton.

Arghyrou, M.G., Kontonikas, A. 2012. The EMU sovereign-debt crisis: Fundamentals, expectations and contagion. Journal of International Financial Markets, Institutions and Money 22, 658- 677

Atukeren, E., 2005. Measuring the strength of cointegration and Granger-causality, Applied Economics Letters 37, 1607-1614.

Azad, A.S.M., Batten, J. A., Fang, V., Wickramanayake, J., 2015. International swap market volatility and contagion. Economic Modelling 47, 355-371.

Baker, S.R., Bloom, N., Davis, S.J., 2013. Measuring economic policy uncertainty. Working Paper No. 13-02, Booth School of Business, The University of Chicago, Chicago.

Bartus, T., 2005. Estimarion of marginal effects using margeff, Stata Journal 5, 309-329.

Beirne, J., Fratzscher, M., 2013. The pricing of sovereign risk and contagion during the European sovereign debt crisis. Journal of International Money and Finance 34, 60-82.

Bekaert, G., Ehrmann, M., Fratzscher, M., Mehl, A. J., 2014. The global crises and equity market contagion. The Journal of Finance 69, 2597-2649.

Caceres, C., Guzzo, V., Segoviano, M. 2010. Sovereign Spreads: Global Risk Aversion, Contagion or Fundamentals?. International Monetary Fund Working Paper 120.

Caporin, M., McAleer, M., 2013. Ten things you should know about the dynamic conditional correlation representation. Econometrics 1, 115-126.

Caporin, M., Pelizzon, L., Ravazzolo, F., Rigobon, R., 2013. Measuring sovereign contagion in Europe. Working Paper 18741, National Bureau of Economic Research, Cambridge, MA.

Celik, S., 2012. The more contagion effect on emerging markets: The evidence of DCCGARCH model. Economic Modelling 29, 1946-1959.

Cheung, Y.-W., Chinn, M. D., 1997. Further investigation of the uncertain unit root in GNP. Journal of Business and Economic Statistics 15, 68-73.

Constâncio, V., 2012. Contagion and the European debt crisis. Financial Stability Review 16, 109-119.

Corsetti, G., Pericoli, M. Sbracia, M., 2005. Some contagion, some interdependence: More pitfalls in tests of financial contagion. Journal of International Money and Finance 24, 1177-1199.

Dolado, J. J., Jenkinson, T., Sosvilla-Rivero, S., 1990. Cointegration and unit roots. Journal of Economic Surveys 4, 149-173.

Dungey, M., Fry, R., Gonzalez-Hermosillo, B., Martin, V., 2005. Empirical modelling of contagion: a review of methodologies. Quantitative Finance 5, 9-24.

Dungey, M., Gajurel, D., 2014. Equity market contagion during the global financial crisis: Evidence from the World's eight largest economies. Economic Systems 38, 161-177.

Eichengreen, B., Rose, A. K., Wyplosz, C., 1996. Contagious currency crises: First tests. Scandinavian Journal of Economics 98, 463-484.

Elliott, G., Thomas, J.R., Stock, J.H., 1996. Efficient tests for an autoregressive unit root. Econometrica 64, 813-836. 
Engle, R.F., 2002. Dynamic conditional correlation: A simple class of multivariate generalized autoregressive conditional heteroskedasticity models. Journal of Business and Economic Statistics 20, 339-350.

Forbes, K., 2013. The big C: Identifying and mitigating contagion, in: The Changing Policy Landscape. Economic Simposium Conference Procedings. Federal Reserve Bank of Kansas City, pp. 23-87.

Forbes, K., Rigobon, R., 2002. No contagion, only interdependence: Measuring stock market comovements. The Journal of Finance 57, 2223-2261.

Goldstein, M., 1998. The Asian Crisis: Causes, Cures, and Systemic Implications. Institute for International Economics, Washington, D. C.

Gómez-Puig, M,. Sosvilla-Rivero, S., 2013. Granger-causality in peripheral EMU public debt markets: A dynamic Approach. Journal of Banking and Finance 37, 4627-4649.

Gómez-Puig, M,. Sosvilla-Rivero, S., 2014. Causality and contagion in EMU sovereign debt markets. International Review of Economics and Finance 33, 12-27.

Granger, C. W. J., 1969. Investigating causal relations by econometric models and crossspectral methods. Econometrica 37, 24-36.

Hakkio, C.S., Keeton, W. R., 2009. Financial stress: What is it, how can it be measured, and why does it matter? Federal Reserve Bank of Kansas City Economic Review, second quarter, 5-50.

Hendry, D.F., 1995. Dynamic Econometrics. Oxford University Press, Oxford.

Hendry, D. F., Mizon, G. E., 1999. The pervasiveness of Granger causality in Econometrics, in Engle, R. F., White, H. (Eds.) Cointegration, Causality, and Forecasting. A Festsschrift in Honour of Clive W. J. Granger, Oxford University Press, Oxford.

Hoover, K. D., 2001. Causality in Macroeconomics. Cambridge University Press, Cambridge.

Hou, Y., Li, S. 2016. Information transmission between U.S. and China index futures markets: An asymmetric DCC GARCH approach. Economic Modelling 52, 884-897.

Hsiao, C., 1981. Autoregressive modelling and money-income causality detection. Journal of Monetary Economics 7, 85-106.

Jeffreys, H., 1961. Theory of Probability. $3^{\text {rd }}$ edition. Oxford University Press, London.

Johansen, S., 1991. Estimation and hypothesis testing of cointegration vectors in Gaussian vector autoregressive models. Econometrica 59, 1551-1580.

Johansen, S., 1995. Likelihood-based Inference in Cointegrated Vector Autoregressive Models. Oxford University Press, Oxford.

Kalbaska, A. \& Gatkowski, M., 2012. Eurozone sovereign contagion: Evidence from the CDS market (2005-2010). Journal of Economic Behaviour and Organization 83, 657-673.

Kaminsky, G. L., Reinhart, C. M., 2000. On crises, contagion, and confusion. Journal of International Economics, 51, 145-168.

Klose, J. \& Weigert, B., 2014. Determinants of sovereign yield spreads during the Eurocrisis-Fundamental factors versus redenomination risk. International Finance 17, 25-50

Kwiatkowski, D., Phillips, P.C.B., Schmidt, P., Shin, P., 1992. Testing the null hypothesis of stationarity against the alternative of a unit root. Journal of Econometrics 54, 159-178.

Lean. H., Tuan, K., 2013. Integration of world leaders and emerging powers into the Malaysian stock market: A DCC-MGARCH approach. Economic Modelling 32, 333-342.

López, R., Navarro, E., 2013. Interest rate and stock return volatility indices for the Eurozone. Investors' gauges of fear during the recent financial crisis. Applied Financial Economics, 23, 1419-1432. 
Lucas, A., Schwaab, B., Zhang, X., 2014. Conditional euro area sovereign default risk. Journal of Business \& Economic Statistics 32, 271-284

Ludwig, A., 2014. A unified approach to investigate pure and wake-up-call contagion: Evidence from the Eurozone's first financial crisis. Journal of International Money and Finance 48, 125-146.

Masson, P., 1999. Contagion: Macroeconomic models with multiple equilibria. Journal of International Money and Finance 18, 587-602.

Metieu, N., 2012. Sovereign risk contagion in the eurozone. Economics Letters 117, 35-38.

Mink, M., De Haan, J., 2013. Contagion during the Greek sovereign debt crisis. Journal of International Money and Finance 34, 102-113.

Mondria, J., Quintana-Domeque, C., 2013. Financial contagion and attention allocation. The Economic Journal 123, 429-454.

Moser, T., 2003. What is international financial contagion?. International Finance 6, 57178.

Ng, S., Perron, P., 2001. Lag length selection and the construction of unit root tests with good size and power. Econometrica 69, 1519-1554.

Pericoli, M., Sbracia, M., 2003. A primer on financial contagion. Journal of Economic Surveys 17, 571-608.

Phillips, P. C. B., Perron, P., 1988. Testing for a unit root in times series regression. Biometrika 75, 335-346.

Philippas, D., Siriopoulos, C. 2013. Putting the "C" into crisis: Contagion, correlations and copulas on EMU bond markets. Journal of International Financial Markets, Institutions and Money 27, 161-176.

Polito, V., Wickens, M. 2011. Assessing the fiscal stance in the European Union and the United States, 1970-2011. Economic Policy 26, 599-647.

Polito, V., Wickens, M. 2012. A model-based indicator of the fiscal stance. European Economic Review 56, 526-551.

Poskitt, D. S., Tremayne, A. R., 1987. Determining a portfolio of linear time series models. Biometrika 74, 125-137.

Sims, C. A., 1972. Money, income, and causality. American Economic Review 62, 540-552.

Singh, M.K., Gómez-Puig, M., Sosvilla-Rivero, S. 2016. Sovereign-Bank linkages: Quantifying directional intensity of risk transfers in EMU countries. Journal of International Money and Finance, forthcoming.

Thornton, D. L., Batten, D. S., 1985. Lag-length selection and tests of Granger causality between money and income. Journal of Money, Credit, and Banking 27, 164-178.

Williams, E. J., 1959. Regression analysis. Wiley, New York.

Yu, I.-W., Fung, K.-P., Tam, C.-S., 2010. Assessing financial market integration in Asia equity markets. Journal of Banking and Finance 34, 2874-2885. 
Figure 1. Daily 10-year sovereign yield spreads over Germany: 1999-2012

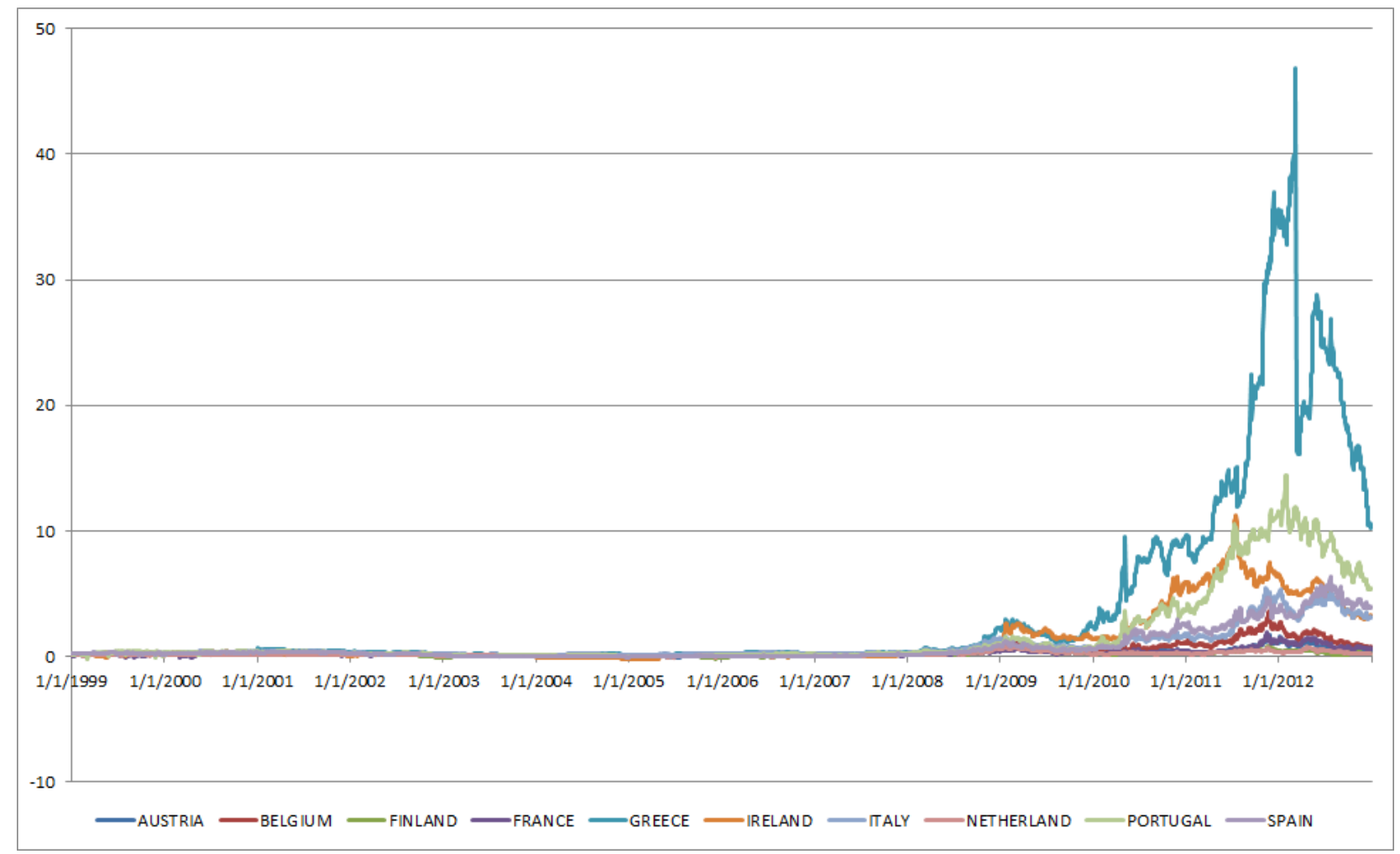

Source: Datastream

Note: Percentage points. 
Figures 2: Contagion episodes: Dynamic Granger-causality methodology Figure 2a: Within peripheral countries

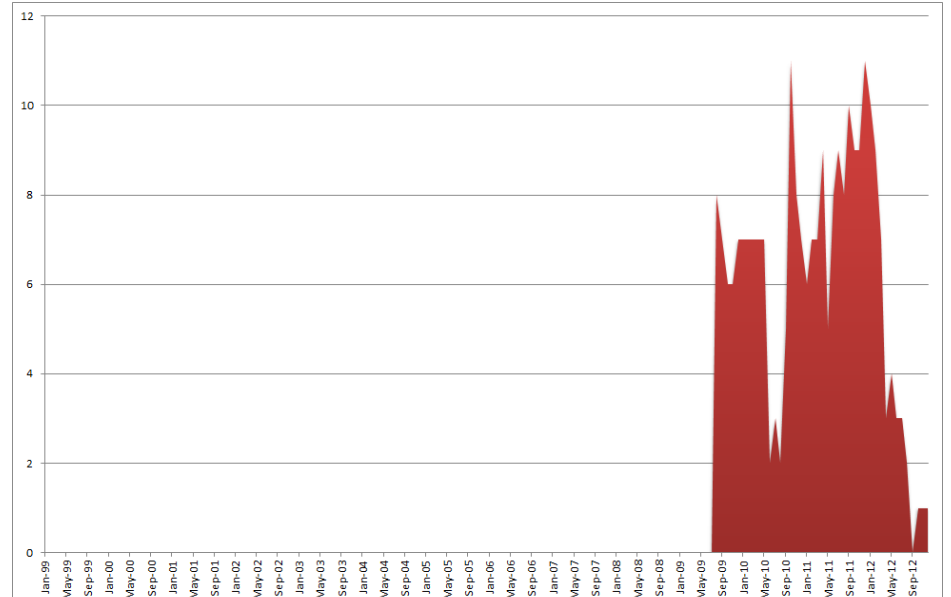

Figure 2c: Within central countries

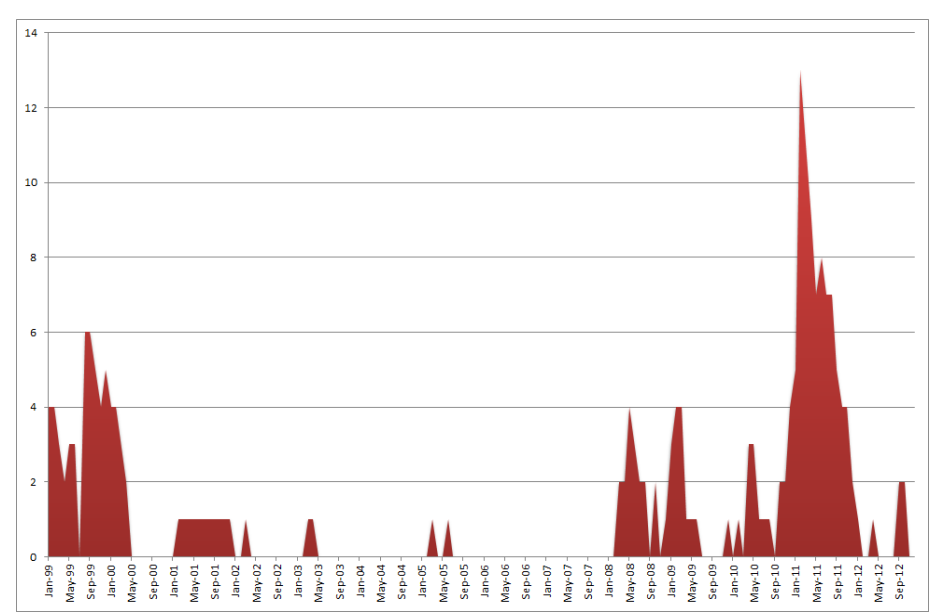

Source: Own estimates. Note: Number of contagion episodes detected
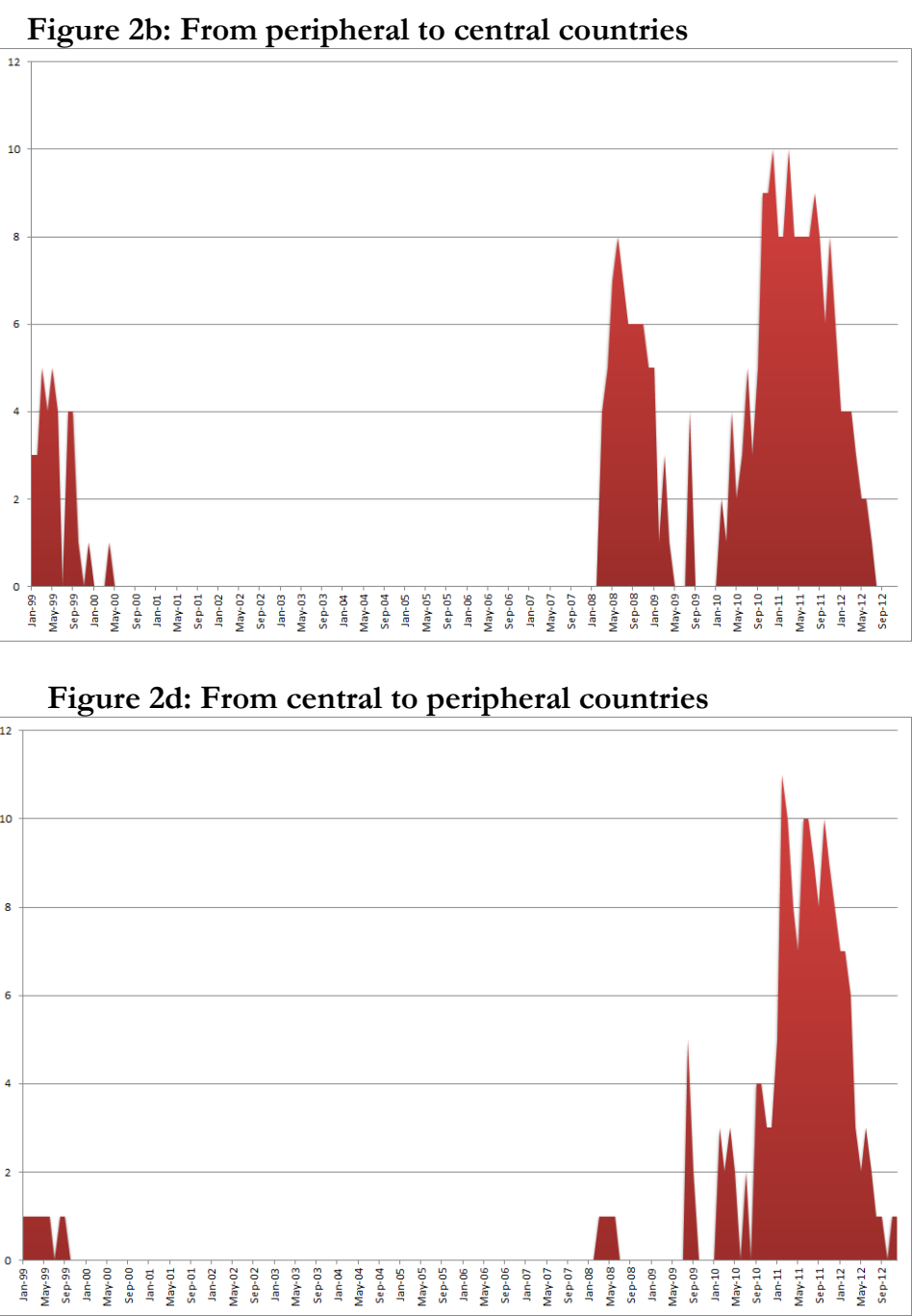
Figures 3: Contagion episodes: DCC-GARCH model Figure 3a: Within peripheral countries

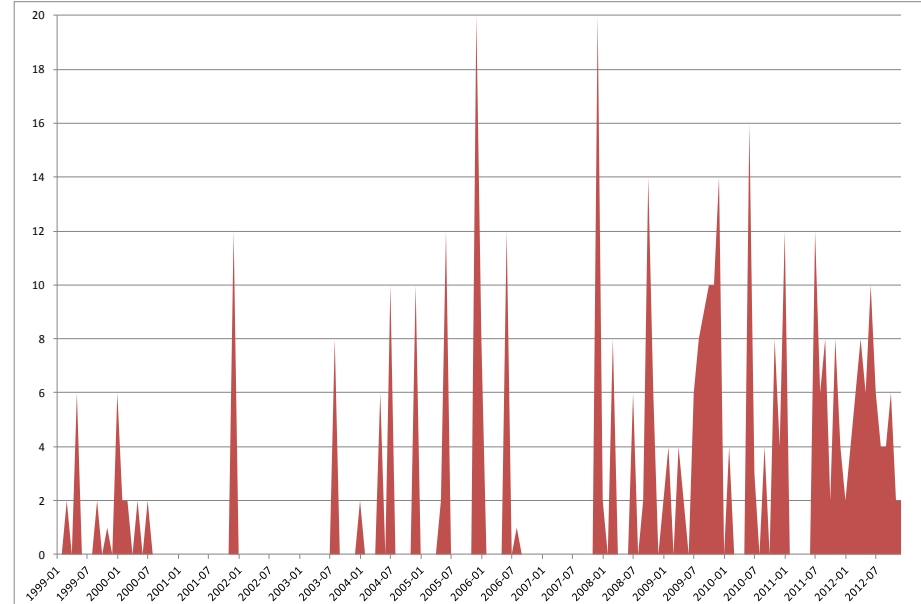

\section{Figure 3c: Within central countries}

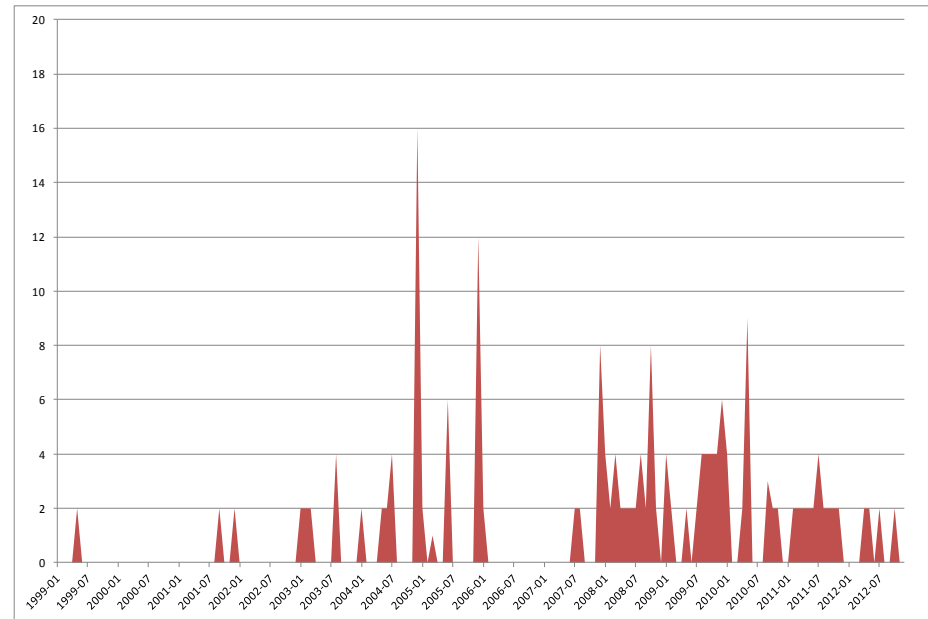

Source: Own estimates. Note: Number of contagion episodes detected
Figure 3b: From peripheral to central countries

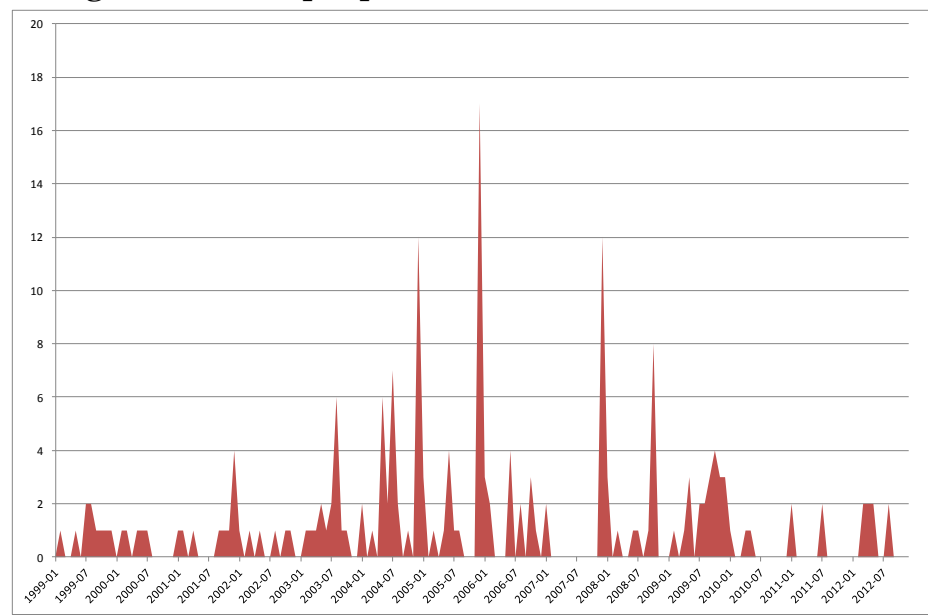

Figure 3d: From central to peripheral countries

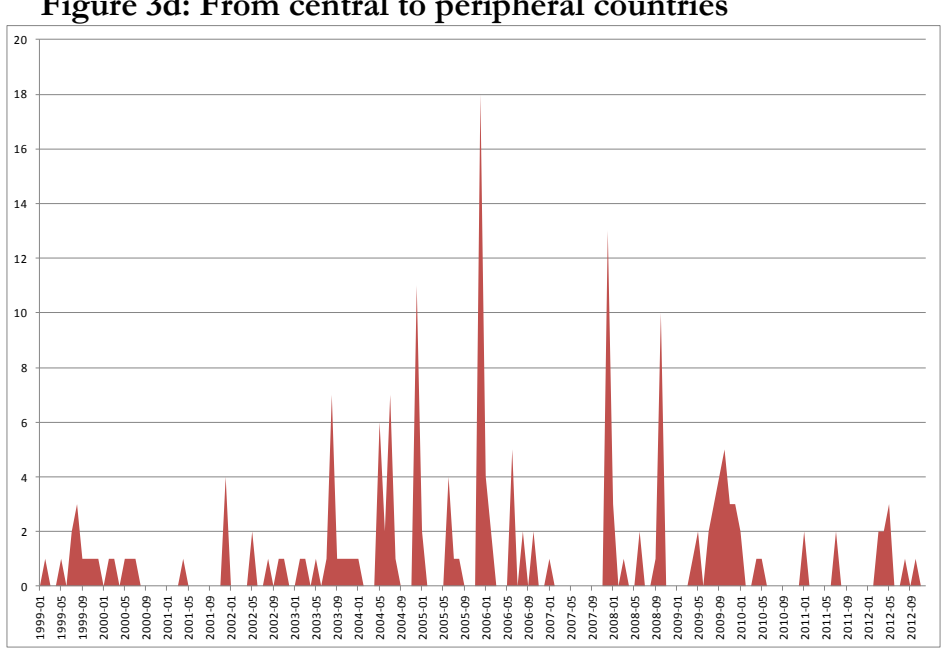


Figure 4: Contagion episodes within all EMU countries

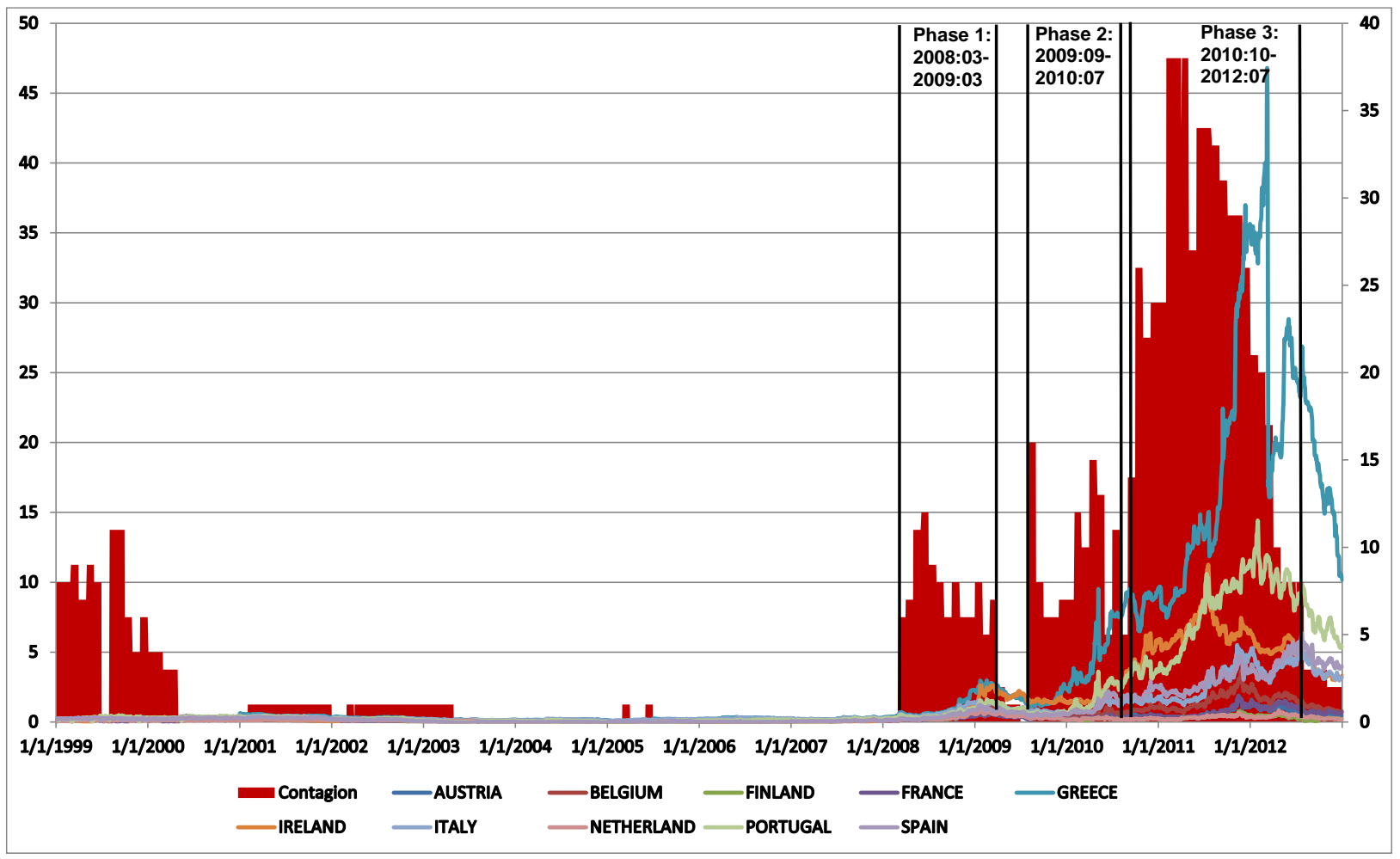

Source: Datastream and own estimates.

Note: Number of contagion episodes detected and daily 10-year sovereign yield spreads over Germany in percentage points jointly with the three phases were contagion episodes are clustered matching the Global Financial Crisis. 
Table 1. Descriptive statistics

Panel A: Levels

\begin{tabular}{|c|c|c|c|c|c|c|c|c|c|c|}
\hline & AUS & BEL & FIN & FRA & GRE & IRE & ITA & NET & POR & SPA \\
\hline Mean & 0.2646 & 0.4347 & 0.1579 & 0.2230 & 3.8092 & 1.2131 & 0.8252 & 0.1637 & 1.5721 & 0.7712 \\
\hline Median & 0.1930 & 0.2681 & 0.1761 & 0.1110 & 0.4613 & 0.1616 & 0.2941 & 0.1332 & 0.2961 & 0.2324 \\
\hline Maximum & 1.8320 & 3.6600 & 0.8270 & 1.8870 & 46.8020 & 11.2490 & 5.4980 & 0.8420 & 14.4100 & 6.3540 \\
\hline Minimum & -0.1358 & -0.1063 & -0.1999 & -0.1126 & 0.0693 & -0.2368 & 0.0610 & -0.1338 & -0.1792 & -0.0593 \\
\hline Std. Dev. & 0.2908 & 0.5397 & 0.1749 & 0.2997 & 7.5759 & 2.1266 & 1.1469 & 0.1568 & 2.9383 & 1.2850 \\
\hline Skewness & 1.6601 & 2.1728 & 0.5639 & 2.3132 & 2.6795 & 1.8265 & 2.2122 & 1.3250 & 2.2040 & 2.0911 \\
\hline Kurtosis & 6.0358 & 8.0628 & 3.2806 & 8.5844 & 9.9743 & 5.3234 & 6.9352 & 4.6350 & 6.6202 & 6.4360 \\
\hline Jarque-Bera & 3080 & 6774 & 206 & 8002 & 11565 & 2852 & 5335 & 1475 & 4951 & 4458 \\
\hline Observations & 3652 & 3652 & 3652 & 3652 & 3588 & 3652 & 3652 & 3652 & 3652 & 3652 \\
\hline
\end{tabular}

Panel B: First differences

\begin{tabular}{|c|c|c|c|c|c|c|c|c|c|c|}
\hline & DAUS & DBEL & DFIN & DFRA & DGRE & DIRE & DITA & DNET & DPOR & DSPA \\
\hline Mean & 0.0001 & 0.0002 & 0.0000 & 0.0002 & 0.0023 & 0.0009 & 0.0008 & 0.0000 & 0.0014 & 0.0010 \\
\hline Median & -0.0001 & 0.0000 & -0.0001 & 0.0000 & 0.0000 & -0.0001 & 0.0001 & 0.0000 & 0.0000 & 0.0000 \\
\hline Maximum & 0.2420 & 0.3240 & 0.2514 & 0.2720 & 7.0300 & 0.8230 & 0.5950 & 0.1631 & 1.7590 & 0.4300 \\
\hline Minimum & -0.2820 & -0.2930 & -0.1537 & -0.2870 & -27.4460 & -1.2127 & -0.7750 & -0.1815 & -1.6546 & -0.8180 \\
\hline Std. Dev. & 0.0242 & 0.0351 & 0.0186 & 0.0305 & 0.5257 & 0.0740 & 0.0579 & 0.0219 & 0.1036 & 0.0577 \\
\hline Skewness & 0.6113 & 0.2052 & 1.3143 & -0.0673 & -39.0312 & -1.0836 & -0.7882 & 0.1401 & 1.0218 & -1.2964 \\
\hline Kurtosis & 25.5464 & 21.4015 & 28.4202 & 19.0731 & 2086.1580 & 48.7009 & 37.5478 & 15.4119 & 74.8098 & 33.7279 \\
\hline Jarque-Bera & 77559 & 51538 & 99352 & 39303 & 649000000 & 318439 & 181947 & 23447 & 785091 & 144659 \\
\hline Observations & 3651 & 3651 & 3651 & 3651 & 3587 & 3651 & 3651 & 3651 & 3651 & 3651 \\
\hline
\end{tabular}

Note: AUS, BEL, FIN, FRA, GRE, IRE, ITA, NET, POR and SPA stand for Austria, Belgium, Finland, France, Greece, Ireland, Italy, the Netherlands, Portugal and Spain.

Table 2. Correlation matrix

\begin{tabular}{|c|c|c|c|c|c|c|c|c|c|c|}
\hline & AUS & BEL & FIN & FRA & GRE & IRE & ITA & NET & POR & SPA \\
\hline AUS & 1.0000 & & & & & & & & & \\
\hline BEL & 0.9018 & 1.0000 & & & & & & & & \\
\hline FIN & 0.8941 & 0.7644 & 1.0000 & & & & & & & \\
\hline FRA & 0.8992 & 0.9518 & 0.7252 & 1.0000 & & & & & & \\
\hline GRE & 0.7457 & 0.8971 & 0.5392 & 0.9137 & 1.0000 & & & & & \\
\hline IRE & 0.7306 & 0.8884 & 0.6281 & 0.8118 & 0.8314 & 1.0000 & & & & \\
\hline ITA & 0.8028 & 0.9274 & 0.6097 & 0.9518 & 0.9467 & 0.8482 & 1.0000 & 0.7039 & & \\
\hline NET & 0.9060 & 0.7963 & 0.8987 & 0.7950 & 0.5834 & 0.6713 & 0.7039 & 1.0000 & & \\
\hline POR & 0.7494 & 0.9199 & 0.5700 & 0.9114 & 0.9635 & 0.9074 & 0.9541 & 0.6272 & 1.0000 & \\
\hline SPA & 0.7305 & 0.8754 & 0.5619 & 0.9035 & 0.9121 & 0.8679 & 0.9730 & 0.6616 & 0.9381 & 1.0000 \\
\hline
\end{tabular}

Note: AUS, BEL, FIN, FRA, GRE, IRE, ITA, NET, POR and SPA stand for Austria, Belgium, Finland, France, Greece, Ireland, Italy, the Netherlands, Portugal and Spain. 
Table 3: Logit models

\begin{tabular}{|c|c|c|c|c|c|c|c|}
\hline \multicolumn{3}{|c|}{ Variables } & \multirow{2}{*}{$\begin{array}{c}\text { All } \\
\text { Countries }\end{array}$} & \multirow{2}{*}{$\begin{array}{c}\text { Peripheral } \\
\text { Countries } \\
-\end{array}$} & \multirow{2}{*}{$\begin{array}{c}\text { Peripheral- } \\
\text { Central } \\
\text { Countries } \\
-\end{array}$} & \multirow[t]{2}{*}{$\begin{array}{c}\text { Central } \\
\text { Countries }\end{array}$} & \multirow{2}{*}{$\begin{array}{c}\begin{array}{c}\text { Central- } \\
\text { Peripheral } \\
\text { countries }\end{array} \\
0.2680^{*} \\
(3.3077) \\
{[0.0346]}\end{array}$} \\
\hline \multirow{8}{*}{$\begin{array}{l}\text { Local market } \\
\text { sentiment }\end{array}$} & \multirow[t]{2}{*}{ Stock Volatility } & XXStockVol & & & & & \\
\hline & & YYStockVol & $\begin{array}{l}0.0157^{*} \\
(4.2523) \\
{[0.0030]}\end{array}$ & - & $\begin{array}{l}0.0080^{*} \\
(3.0451) \\
{[0.0009]}\end{array}$ & - & \\
\hline & \multirow[t]{2}{*}{$\begin{array}{l}\text { Index of the } \\
\text { Fiscal stance }\end{array}$} & XXIFS & - & $\begin{array}{c}17.4396^{*} \\
(5.7115) \\
{[1.4616]}\end{array}$ & $\begin{array}{l}4.1177^{*} \\
(3.5417) \\
{[0.4751]}\end{array}$ & - & \\
\hline & & YYIFS & $\begin{array}{l}3.5457^{*} \\
(7.9216) \\
{[0.6753]}\end{array}$ & $\begin{array}{l}1.7466^{*} \\
(7.7230) \\
{[0.1464]}\end{array}$ & - & - & \\
\hline & \multirow[t]{2}{*}{$\begin{array}{l}\text { Consumer } \\
\text { Confidence } \\
\text { Indicator }\end{array}$} & XXCCI & - & - & $\begin{array}{l}-0.0163^{*} \\
(-3.4371) \\
{[-0.0019]}\end{array}$ & - & $\begin{array}{c}-0.2620 * \\
(-3.4511) \\
{[-0.0338]}\end{array}$ \\
\hline & & YYCCI & $\begin{array}{l}-0.0229 * \\
(-3.8419) \\
{[-0.0044]}\end{array}$ & - & $\begin{array}{l}-0.0685^{*} \\
(-4.3512) \\
{[-0.0079]}\end{array}$ & $\begin{array}{l}0.0178^{*} \\
(3.8421) \\
{[0.0019]}\end{array}$ & $\begin{array}{c}-0.1577 \\
(-4.3410) \\
[-0.0204]]\end{array}$ \\
\hline & \multirow[t]{2}{*}{ Rating } & XXRating & $\begin{array}{l}0.0769^{*} \\
(7.6320) \\
{[0.0146]}\end{array}$ & - & $\begin{array}{l}0.4157^{*} \\
(7.1308) \\
{[0.0537]}\end{array}$ & $\begin{array}{l}2.9916^{*} \\
(4.1555) \\
{[0.3180]}\end{array}$ & $\begin{array}{l}0.4157^{*} \\
(3.7348) \\
{[0.0537]}\end{array}$ \\
\hline & & YYRating & $\begin{array}{l}0.0270^{*} \\
(3.9255) \\
{[0.0051]}\end{array}$ & - & $\begin{array}{l}0.2202^{*} \\
(3.6813) \\
{[0.0285]}\end{array}$ & - & $\begin{array}{l}0.2202^{*} \\
(3.6807) \\
{[0.0285]}\end{array}$ \\
\hline \multirow{10}{*}{$\begin{array}{l}\text { Local macro } \\
\text { fundamentals }\end{array}$} & $\begin{array}{l}\text { Net position } \\
\text { towards } \\
\text { the rest of the } \\
\text { world }\end{array}$ & XXCA & $\begin{array}{c}-0.0648^{*} \\
(3.9813) \\
{[-0.0123]}\end{array}$ & - & - & $\begin{array}{c}-0.5089 * \\
(-3.9809) \\
{[-0.0541]}\end{array}$ & - \\
\hline & \multirow[t]{2}{*}{ Growth potential } & XXU & $\begin{array}{l}0.119)^{*} \\
(7.8508) \\
{[0.0228]}\end{array}$ & - & $\begin{array}{l}1.5410^{*} \\
(7.3517) \\
{[0.1106]}\end{array}$ & $\begin{array}{l}1.1715^{*} \\
(3.8731) \\
{[0.1245]}\end{array}$ & $\begin{array}{l}0.8551 * \\
(3.6722) \\
{[0.1105]}\end{array}$ \\
\hline & & YYU & $\begin{array}{l}0.1202^{*} \\
(6.3508) \\
{[0.0229]}\end{array}$ & $\begin{array}{l}0.7273^{*} \\
(4.1905) \\
{[0.0601]}\end{array}$ & - & $\begin{array}{l}1.6867^{*} \\
(3.6499) \\
{[0.1793]}\end{array}$ & - \\
\hline & \multirow[t]{2}{*}{ Competitiveness } & XXINF & $\begin{array}{l}0.2862^{*} \\
(3.8943) \\
{[0.0545]}\end{array}$ & - & $\begin{array}{l}1.5410^{*} \\
(3.9345) \\
{[0.1991]}\end{array}$ & $\begin{array}{l}2.0884^{*} \\
(4.3445) \\
{[0.2220]}\end{array}$ & $\begin{array}{c}-1.5410^{*} \\
(3.3371 \\
{[0.1991]}\end{array}$ \\
\hline & & YYINF & $\begin{array}{l}0.6057^{*} \\
(5.1983) \\
{[0.1154]}\end{array}$ & $\begin{array}{l}0.9125^{*} \\
(7.3321) \\
{[0.0765]}\end{array}$ & $\begin{array}{l}1.9076^{*} \\
(3.7514) \\
{[0.2465]}\end{array}$ & - & $\begin{array}{l}1.9076^{*} \\
(3.7552) \\
{[0.2465]}\end{array}$ \\
\hline & \multirow[t]{3}{*}{ Fiscal Position } & XXDEBT & $\begin{array}{l}0.0155^{*} \\
(2.8754) \\
{[0.0035]}\end{array}$ & - & $\begin{array}{l}0.0880^{*} \\
(3.8184) \\
{[0.0114]}\end{array}$ & $\begin{array}{c}0.2513^{*} \\
(3.85612) \\
{[0.0267]}\end{array}$ & $\begin{array}{l}0.0880^{*} \\
(3.1337) \\
{[0.0114]}\end{array}$ \\
\hline & & YYDEBT & $\begin{array}{l}0.0133^{*} \\
(2.9143) \\
{[0.0026]}\end{array}$ & $\begin{array}{c}0.1673^{*} \\
(5.4604) \\
{[0.0140]}\end{array}$ & $\begin{array}{l}0.1658^{*} \\
(5.0901) \\
{[0.0214]}\end{array}$ & - & $\begin{array}{l}0.2658^{*} \\
(5-0911) \\
{[0.0214]}\end{array}$ \\
\hline & & YYDEF & & - & - & - & $\begin{array}{l}0.0807 * \\
(3.8378) \\
{[0.0104]}\end{array}$ \\
\hline & \multirow[t]{2}{*}{ Market liquidity } & XXLIQ & - & $\begin{array}{l}-0.0050^{*} \\
(-5.3712) \\
{[-0.0004]}\end{array}$ & - & $\begin{array}{c}-0.0023^{*} \\
(-3.6382) \\
{[-0.0005]}\end{array}$ & $\begin{array}{l}-0.0051 \\
(-5.1827) \\
{[-0.0007]}\end{array}$ \\
\hline & & YYLIQ & & - & $\begin{array}{l}-0.0051 * \\
(-5.1831) \\
{[-0.0007]}\end{array}$ & $\begin{array}{c}-0.0141 * \\
(-3.1289) \\
{[-0.0015]}\end{array}$ & - \\
\hline
\end{tabular}


Table 3 (continued)

\begin{tabular}{|c|c|c|c|c|c|c|c|}
\hline \multicolumn{3}{|c|}{ Variables } & $\begin{array}{c}\text { All } \\
\text { Countries }\end{array}$ & $\begin{array}{l}\text { Peripheral } \\
\text { Countries }\end{array}$ & $\begin{array}{c}\text { Peripheral- } \\
\text { Central }\end{array}$ & $\begin{array}{c}\text { Central } \\
\text { Countries }\end{array}$ & $\begin{array}{c}\text { Central- } \\
\text { Peripheral }\end{array}$ \\
\hline \multirow{4}{*}{$\begin{array}{c}\text { Regional } \\
\text { market } \\
\text { sentiment }\end{array}$} & Credit Spread & EURCreditSpread & - & $\begin{array}{l}0.6913^{*} \\
(8.1606) \\
{[0.0579]}\end{array}$ & - & $\begin{array}{l}1.4389 * \\
(3.9986) \\
{[0.1529]}\end{array}$ & \\
\hline & ITRAXX $_{\text {FIN }}$ & EURITRAXX $_{\text {FIN }}$ & & - & $\begin{array}{c}0.0330^{*} \\
(2.8964) \\
{[0.0043]}\end{array}$ & & \\
\hline & ITRAXX $_{\mathrm{NF}}$ & EURITRAXX $_{\mathrm{NF}}$ & & - & - & $\begin{array}{c}0.0813^{*} \\
(3.5812) \\
{[0.0086]}\end{array}$ & $\begin{array}{c}0.0330^{*} \\
(3.6213) \\
{[0.0176]}\end{array}$ \\
\hline & Euro Instability & EURInstability & $\begin{array}{c}11.4764^{*} \\
(3.5111) \\
{[2.1858]}\end{array}$ & $\begin{array}{c}63.1799 * \\
(5.4212) \\
{[5.2950]}\end{array}$ & $\begin{array}{c}126.4706^{*} \\
(3.8005) \\
{[1.6343]}\end{array}$ & $\begin{array}{c}27.2055^{*} \\
(2.8994) \\
{[0.2891]}\end{array}$ & $\begin{array}{l}6.9165^{*} \\
(3.5821) \\
{[0.7980]}\end{array}$ \\
\hline $\begin{array}{l}\text { Financial } \\
\text { Linkages }\end{array}$ & $\begin{array}{c}\text { Cross-border } \\
\text { banking linkages }\end{array}$ & XXYYBAN & $\begin{array}{l}0.0194^{*} \\
(3.8213) \\
{[0.0037]}\end{array}$ & - & $\begin{array}{l}0.0147^{*} \\
(3.6934) \\
{[0.0017]}\end{array}$ & - & - \\
\hline \multicolumn{3}{|c|}{ Individual dummies } & YES & YES & YES & YES & YES \\
\hline \multicolumn{3}{|c|}{ Time dummies } & NO & NO & YES & YES & NO \\
\hline \multicolumn{3}{|c|}{ Pseudo $\mathbf{R}^{2}$} & 0.3577 & 0.3750 & 0.4096 & 0.3535 & 0.4096 \\
\hline \multicolumn{3}{|c|}{ Count $\mathbf{R}^{2}$} & 0.6754 & 0.7779 & 0.7448 & 0.7676 & 0.6552 \\
\hline \multicolumn{3}{|c|}{ Log likelihood } & -685.6621 & -297.7433 & -115.2336 & -687.4604 & -115.2336 \\
\hline \multicolumn{3}{|c|}{$\chi^{2}$} & $197.20 *$ & $169.49 *$ & 64.16* & $246.71 *$ & 64.16* \\
\hline \multicolumn{3}{|c|}{ Prob individual dummies $=0$} & $0.0000^{*}$ & $0.0000^{*}$ & $0.0000^{*}$ & $0.0000^{*}$ & $0.0000^{*}$ \\
\hline \multicolumn{3}{|c|}{ Prob time dummies $=0$} & 0.8632 & 0.6700 & $0.0000^{*}$ & $0.0000^{*}$ & 0.8111 \\
\hline \multicolumn{3}{|c|}{$\begin{array}{l}\text { Prob individual dummies } \\
\text { and time dummies }=0\end{array}$} & - & $0.0000 *$ & $0.0000^{*}$ & $0.0000 *$ & $0.0000^{*}$ \\
\hline \multicolumn{3}{|c|}{ Observations } & 1226 & 925 & 290 & 287 & 290 \\
\hline \multicolumn{3}{|c|}{ Country pairs } & 90 & 20 & 25 & 20 & 25 \\
\hline
\end{tabular}

Notes: In the ordinary brackets below the parameter estimates are the corresponding z-statistics. In the square brackets, the associated marginal effects are given.* and $* *$ denote significance at the $1 \%$ and $5 \%$ level, respectively Count $\mathrm{R}^{2}$ is the proportion of outcomes correctly predicted by the model

$\mathrm{XX}$ denotes trigger country and YY receiver country in the pair-wise causal relationship 